\title{
Inositol Lipids and Signal Transduction in the Nervous System: An Update
}

\author{
*Stephen K. Fisher, Anne M. Heacock, and †Bernard W. Agranoff \\ Neuroscience Laboratory and Departments of *Pharmacology and $\uparrow$ Biological Chemistry, \\ University of Michigan, Ann Arbor, Michigan, U.S.A.
}

The role that inositol lipids play in cellular signaling events in eukaryotic cells remains one of the most intensively investigated areas of cell biology. In this respect, phosphoinositide-mediated signal transduction in the CNS is no exception; major advances have been made since a previous review on this subject (Fisher and Agranoff, 1987). Not only have stimulated phosphoinositide turnover and its physiological sequelae been demonstrated repeatedly in a variety of neural preparations, but, in addition, the detailed molecular mechanisms underlying these events continue to unfold. Here we review the progress that has occurred in selected aspects of this topic since 1987. In the first two sections of this article, emphasis is placed on novel functional roles for the inositol lipids and on recent insights into the molecular characteristics and regulation of three key components of the phosphoinositide signal transduction system, namely, the inositol lipid kinases, phospholipases C (PLCs), and the inositol 1,4,5-trisphosphate $\left[\mathrm{I}(1,4,5) \mathrm{P}_{3}\right]$ receptor. The metabolic fate of $\mathrm{I}(1,4,5) \mathrm{P}_{3}$ in neural tissues, as well as its control, is also detailed. Later we focus on identification of the multiple receptor subtypes that are coupled to inositol lipid turnover and discuss possible strategies for intervention into phosphoinositide-mediated signal transduction. Due to space limitations, an extensive evaluation of the diacylglycerol/protein kinase C (DAG/ PKC) limb of the signal transduction pathway is not included (for reviews, see Nishizuka, 1988; Kanoh et al., 1990).

\section{INOSITOL LIPIDS AND ENZYMES OF THEIR METABOLISM}

\section{Phosphoinositides and cell function: new roles}

It is by now well-established that the major inositolcontaining lipids that serve as precursors of intracellular second messenger molecules in both neural and nonneural tissues are phosphatidylinositol (PI), phosphatidylinositol 4-phosphate (PIP), and phosphatidylinositol 4,5-bisphosphate $\left(\mathrm{PIP}_{2}\right)$. However, recent studies indicate the additional presence of a number of quantitatively minor inositol lipids that are characterized by the presence of a phosphate group at the D-3 position of the inositol ring. Although much of the evidence accumulated for the existence of these lipids comes from nonneural tissues (for review, see Carpenter and Cantley, 1990), PI(3)P has been identified in 1321 NI astrocytoma cells (Stephens et al., 1989) and in NG 1 15-401 L-C3 neuroblastoma cells (Poyner et al., 1990), and phosphatidylinositol 3,4,5-trisphosphate $\left(\mathrm{PIP}_{3}\right)$ in cerebral cortex (Vadnal and Parthasarathy, 1989). Because the 3-phosphoinositides are only poorly separated from their quantitatively major counterparts by present TLC methods, definitive identification of the lipid structure requires an initial removal of the glycerol backbone to yield the inositol phosphate, followed by periodate oxidation, reduction, and dephosphorylation to the corresponding polyol. Although such rigorous analysis has been used for identification of PI(3)P in astrocytoma cells (Stephens et al., 1989), in
Address correspondence and reprint requests to Dr. S. K. Fisher at Neuroscience Laboratory, University of Michigan. $1103 \mathrm{E}$. Huron St., Ann Arbor, MI 48104-1687, U.S.A.

Abbreviations used: ACPD, 1-aminocyclopentyl-1,3-dicarboxylic acid: $\left[\mathrm{Ca}^{2+}\right]_{i}$, concentration of intracellular $\mathrm{Ca}^{2+} ; \mathrm{CDP}-\mathrm{DAG}$, cytidine diphosphodiacylglycerol; DAG, diacylglycerol; ET, endothelin; $G$ protein, guanine nucleotide binding protein; $G_{\mathfrak{p}}$, putative $G$ protein that regulates PLC activity: GTP $\gamma \mathrm{S}$, guanosine $5^{\prime}-O-(3$-thiotriphosphate): $\mathrm{IP}_{1}$, myo-inositol monophosphate; $\mathrm{IP}_{2}$, myo-inositol bisphosphate; $\mathrm{IP}_{3}$, myo-inositol trisphosphate; $\mathrm{IP}_{4}$, myo-inositol tetra- kisphosphate; $\mathrm{IP}_{5}, m y\left(-\right.$-inositol pentakisphosphate; $\mathrm{IP}_{6}$, myo-inositol hexakisphosphate; (numbering of phosphate groups is related to the 1-D structure of PI); mAChR, muscarinic acetylcholine receptor; PI, phosphatidylinositol; PIP, phosphatidylinositol 4-phosphate; PIP $_{2}$, phosphatidylinositol 4.5-bisphosphate; $\mathrm{PIP}_{3}$, phosphatidylinositol 3,4.5-trisphosphate; (positions of phosphate groups are designated when different from those indicated); PKA, protein kinase A; PKC, protein kinase C; $\mathrm{PLA}_{2}$, phospholipase $\mathrm{A}_{2} ;$ PLC, phospholipase $\mathrm{C}$; SDS-PAGE, sodium dodecylsulfate-polyacrylamide gel electrophoresis; SRTX, sarafotoxin. 
most instances, structures of the 3-phosphoinositides have been inferred from a comparison of HPLC elution profiles of deacylated lipid products with authentic standards. The physiological role of these novel phosphoinositides is not yet known. Upon the addition of carbachol to astrocytoma cells, a slow but marked decrease in PI(3)P radiolabel was noted (Stephens et al., 1989). In contrast, labeling of the same lipid was unaltered following the addition of either mitogenic or nonmitogenic stimuli to NG 115-401L-C3 cells (Poyner et al., 1990). Although the 3-phosphoinositides were first identified in cells that undergo rapid cell division, PI(3)P has now been identified in both proliferative and nonproliferative tissues (Downes and MacPhee, 1990). Furthermore, because these phosphoinositides are present only in trace concentrations and do not serve as substrates for PLC activity (Lips et al., 1989; Serunian et al., 1989), their role as precursors of second messenger molecules appears unlikely. This raises the possibility that the 3-phosphoinositides undergo further metabolism, e.g., dephosphorylation (see Lips and Majerus, 1989).

A separate role for inositol lipids in the maintenance of the cytoskeleton has also been proposed based upon the known ability of $\mathrm{PIP}_{2}$ to bind to actin-binding proteins, the best documented of which is gelsolin. Bound $\mathrm{PIP}_{2}$ facilitates the release of gelsolin from the actin filament, thereby regulating new filament formation (for review, see Majerus et al., 1990). PIP $_{2}$ also binds with high affinity $\left(K_{\mathrm{D}}<0.1 \mu M\right)$ to profilin, a protein which inhibits actin polymerization (GoldschmidtClermont et al., 1990). It is possible that PIP $_{2}$ thus promotes actin polymerization by regulation of the gelsolin-actin and profilin-actin complexes. Recently, a direct role for phosphoinositides in exocytosis from chromaffin cells was proposed (Eberhard et al., 1990). It is conceivable that, in these cells, cytoskeletal elements involved in exocytosis are regulated by the inositol lipids.

The presence of a PI glycan in brain was first indicated some 30 years ago by Klenk and Hendricks (1961), who demonstrated that human brain contained an inositol lipid with glucosamine, mannose, and ethanolamine. In both neural and nonneural cells, PI glycans may anchor proteins to the outer membrane leaflet (thereby conferring increased lateral mobility). The common structural features of this attachment are an ethanolamine residue with an amide linkage to the terminal carboxyl group of the protein, a mannose-containing glycan, and a nonacetylated glucosamine residue linked to the D-6 position of myo-inositol via a glycosidic linkage (for reviews, see Low, 1989; Lisanti et al., 1990). In brain, Thy-1 and a number of other cell-surface glycoproteins, the expression of which may be regulated during development, are anchored to the membrane via glycosyl PI linkages (Low and Kincade, 1985; Margolis et al., 1988). Moreover, brain contains at least two PLC activities which appear specific for the glycosylated form of PI (Fouchier et al., 1990). Un- like the bulk of cellular PI in which stearate and arachidonate predominate, these substituents are no longer prominent in PI anchors, being replaced in various tissues and species by myristate, octadecanol (as a 1-alkyl substituent), or docosanoate. In $\mathrm{PC} 12$ pheochromocytoma cells, the addition of nerve growth factor stimulates both the production of a $\left[{ }^{3} \mathrm{H}\right]$ myristate-labeled species of DAG (but not that of $\left[{ }^{3} \mathrm{H}\right]$ arachidonyl-DAG) and an inositol phosphate glycan (Chan et al., 1989). The latter may serve as an intracellular second messenger, as has been proposed for insulin action (Lisanti et al., 1990). The possibility that D-chiro-inositol-anchored proteins occur (Ferguson and Williams, 1988; Kennington et al., 1990) must also be considered.

\section{Phosphoinositide kinases and their regulation}

Although the concept that multiple forms of PI kinase might exist in tissues was first raised over 20 years ago (Harwood and Hawthorne, 1969), only recently have distinct forms of the enzyme been isolated and purified from brain. At least three forms of PI kinase can be distinguished on the basis of the product formed, $M_{r}$, ATP requirement, effects of detergents, and inhibition by adenosine (Table 1A). A type I or PI 3-kinase, originally purified from fibroblasts (Whitman et al., 1987), has been purified to near homogeneity from bovine brain cytosol (Morgan et al., 1990). This kinase specifically phosphorylates PI at the D-3 (rather than the D-4) position of myo-inositol, is strongly inhibited by detergents, and exhibits a high affinity for ATP. This enzyme will also phosphorylate added PIP and PIP $\mathrm{P}_{2}$ to a comparable extent with the presumed formation of $\mathrm{PI}(3,4) \mathrm{P}_{2}$ and PIP $_{3}$, respectively (Morgan et al., 1990). Two additional 4-kinase activities have been described by Endemann et al. (1987), both of which are specific for PI. One (type II PI kinase) can be distinguished from PI 3-kinase in that it is an integral membrane protein, phosphorylates only at the D-4 position, is of a lower $M_{r}$, and is activated by detergents. It is also potently inhibited by adenosine. A type III PI kinase is also present in brain and shows the same phosphorylation pattern as type II PI kinase, but exhibits a larger $\mathbf{M}_{\mathbf{r}}$ and a lower affinity for ATP. Recently, a monoclonal antibody has been developed which is highly specific for the type II kinase (Endemann et al., 1991). Saltiel et al. (1987) have also isolated a 4-kinase activity from myelin which is distinct from that described as type I, but phosphorylates both PI and PIP. Little is known of the regulation of PI kinase activities in brain. In contrast, in nonneural cells, inhibition and activation of enzyme activity by adenosine and polyamines, respectively, have been proposed (Endemann et al., 1987; Downes and MacPhee, 1990).

PIP 5-kinases are present in both the cytosol and brain membranes, although they predominate in the former (Table 1B). These enzymes phosphorylate PIP, but not PI, and have been purified from both the cytosol and membranes. There is some suggestion that PIP 
TABLE 1. Biochemical characteristics of phosphoinositide kinases in brain

\begin{tabular}{|c|c|c|c|c|c|c|c|c|}
\hline & Source & $\mathbf{M}_{\mathbf{r}}$ & Substrate & Product & $\begin{array}{c}K_{\mathrm{m}}(\mathrm{ATP}) \\
(\mu M)\end{array}$ & Detergent & $\begin{array}{c}K_{\mathrm{i}} \text { (adenosine) } \\
(\mu M)\end{array}$ & Reference \\
\hline \multicolumn{9}{|l|}{ A. PI kinases } \\
\hline Type I & $\begin{array}{l}\text { Bovine brain } \\
\text { (whole brain) }\end{array}$ & $85 \mathrm{~K}$ & $\begin{array}{l}\text { PI } \\
\text { PIP } \\
\text { PIP }_{2}\end{array}$ & $\begin{array}{l}\mathrm{PI}(3) \mathrm{P} \\
\mathrm{PIP}_{2} \\
\mathrm{PIP}_{3}\end{array}$ & 67 & Inhibition & ND & Morgan et al. (1990) \\
\hline Type II & $\begin{array}{l}\text { Bovine brain } \\
\text { (membranes) }\end{array}$ & $55 \mathrm{~K}$ & $\mathrm{PI}$ & PIP & 54 & Activation & 18 & Endemann et al. (1987) \\
\hline \multirow[t]{2}{*}{ Type III } & $\begin{array}{l}\text { Bovine brain } \\
\text { (membranes) }\end{array}$ & $230 \mathrm{~K}$ & PI & PIP & 742 & Activation & 1.520 & Endemann et al. (1987) \\
\hline & $\begin{array}{l}\text { Rat brain } \\
\text { (membranes) }\end{array}$ & $76 \mathrm{~K}$ & PI & PIP & 150 & Activation & 200 & $\begin{array}{l}\text { Yamakawa and Takenawa } \\
(1988)\end{array}$ \\
\hline$?$ & $\begin{array}{l}\text { Bovine brain } \\
\text { (myelin) }\end{array}$ & $45 \mathrm{~K}$ & $\begin{array}{l}\text { PI } \\
\text { PIP }\end{array}$ & $\begin{array}{l}\mathrm{PIP}_{2} \\
\mathrm{PIP}_{2}\end{array}$ & 150 & ND & ND & Saltiel et al. (1987) \\
\hline \multirow[t]{3}{*}{ B. PIP 5-kinase } & $\begin{array}{l}\text { Rat brain } \\
\text { (cytosol) }\end{array}$ & $45 \mathrm{~K}$ & PIP & $\mathrm{PIP}_{2}$ & 25 & & & $\begin{array}{l}\text { Cochet and Chambaz } \\
(1986)\end{array}$ \\
\hline & $\begin{array}{l}\text { Rat brain } \\
\text { (cytosol) }\end{array}$ & $45 \mathrm{~K}$ & PIP & $\mathrm{PIP}_{2}$ & ND & & & Van Dongen et al. (1984) \\
\hline & $\begin{array}{l}\text { Bovine brain } \\
\text { (membranes) }\end{array}$ & $110 \mathrm{~K}$ & PIP & $\mathbf{P I P}_{2}$ & ND & & & Mortiz et al. (1990) \\
\hline
\end{tabular}

ND, not determined.

kinase in brain membranes may be activated by GTP and its nonhydrolyzable analogues, an effect apparently not mediated via an inhibition of phosphomonoesterase or PLC activities (Smith and Chang, 1989; Strosznajder and Strosznajder, 1989). A further means of regulation of PIP kinase may be through a brain-specific protein $\mathrm{B}_{50}$, which upon phosphorylation by PKC, inhibits PIP kinase (Van Hooff et al., 1988).

\section{PLC and its regulation}

Multiple forms of PLC are now known to exist in both neural and nonneural tissues. The five isozymes thus far identified (designated as $\alpha, \beta, \gamma, \delta$, and $\epsilon$, based upon the chronological order of their purification) are immunologically distinct entities and the products of separate genes (Rhee et al., 1989). In addition, a number of isoforms presumed to reflect proteolytic cleavage of the parent enzymes have been identified and purified. Amino acid sequence data indicate that only a very limited homology exists between the $\beta, \gamma$, and $\delta$ isozymes, whereas none is observed for PLC- $\alpha$. The two regions of homology include one of approximately 150 and a second of 120 amino acid residues which are $54 \%$ and $42 \%$ identical between the isozymes, respectively, but are differentially localized within each isozyme. PLC- $\gamma$ also exhibits some amino acid sequences that are related to those found in nonreceptor tyrosine kinases of the $s r c$ family, GTPase-activating protein, and $\alpha$-spectrin. Deletion mutant forms of PLC that lack portions of these sequences retain enzyme activity, thereby indicating that they serve a regulatory, rather than catalytic function (Emori et al., 1989).

Of the five known isozymes, PLC- $\beta,-\gamma$, and $-\delta$ predominate in brain and have been extensively purified from a variety of sources (Table 2). The cDNA se- quences of the $\beta, \gamma$, and $\delta$ forms of brain PLC have also been elucidated and antibodies to these isozymes raised. Although PLC has been purified routinely from cytosol, enzyme activity is also present in membrane fractions, the proportions of PLC activity present in each cellular compartment being isozyme-specific (Lee et al., 1987). Confirmation that the same enzyme activity may reside in both cytosol and membrane fractions was obtained by Lee et al. (1987), who demonstrated that PLC- $\beta$ activities derived either from $\mathrm{KCl}$ washed membranes or from cytosol had similar $M_{r}$ values, were recognized by the same monoclonal antibodies, and exhibited a similar elution profile of tryptic peptides. Although the bimodal subcellular distribution of PLC has raised the suggestion that the enzyme undergoes translocation, there is little direct evidence for this at present. The availability of monoclonal antibodies to PLC- $\beta,-\gamma$, and $-\delta$ has permitted studies of the regional and cellular distribution of the isozymes

TABLE 2. $P L C$ isozymes isolated from brain

\begin{tabular}{clrl}
\hline PLC isozyme & \multicolumn{1}{c}{ Source } & \multicolumn{1}{c}{$\mathrm{M}_{\mathrm{r}}$} & \multicolumn{1}{c}{ Reference } \\
\hline$\beta-1$ & Bovine brain & $150 \mathrm{~K}$ & Ryu et al. (1986, 1987a,b) \\
& Bovine brain & $154 \mathrm{~K}$ & Katan and Parker (1987) \\
& Rabbit brain & $155 \mathrm{~K}$ & Carter et al. (1990b) \\
$\beta-2$ & Bovine brain & $140 \mathrm{~K}$ & Ryu et al. (1987a,b) \\
$\beta-3$ & Bovine brain & $100 \mathrm{~K}$ & Ryu et al. (1986, 1987a,b) \\
$\gamma$ & Bovine brain & $145 \mathrm{~K}$ & Ryu et al. (1986, 1987a,b) \\
$\delta$ & Bovine brain & $85 \mathrm{~K}$ & Ryu et al. (1987a,b) \\
& Rat brain & $85 \mathrm{~K}$ & Homma et al. (1988) \\
& Bovine brain & $88 \mathrm{~K}$ & Rebecchi and Rosen (1987) \\
$(\epsilon)$ & Rat brain & $85 \mathrm{~K}$ & Homma et al. (1988) \\
\hline
\end{tabular}


within the CNS. Whereas PLC- $\gamma$ is distributed relatively uniformly within neurons in all brain regions, PLC- $\beta$ immunoreactivity is most concentrated in neurons present in the globus pallidus, substantia nigra, cerebral cortex, hippocampus, and thalamic nuclei (Gerfen et al., 1988). In contrast, PLC- $\delta$ immunoreactivity appears preferentially localized to glial cells in all brain areas examined (Choi et al., 1989).

The activity of PLC is strongly dependent upon the assay conditions chosen. However, when conditions comparable to those of the intracellular ionic environment are used ( $\mathrm{pH} 7$, high $\mathrm{K}^{+},\left[\mathrm{Ca}^{2+}\right] \leq 1 \mu M$ ), two key properties of PLC become evident. The first is that for all isozymes (in particular, PLC- $\beta$; see Rhee et al., 1989), PIP 2 and PIP are the preferred substrates. Inositol lipids containing a 3'-phosphate do not appear to serve as substrates for PLC (Lips et al., 1989; Serunian et al., 1989). The specificity with which the polyphosphoinositides are hydrolyzed in vitro by PLC is consistent with studies of their receptor-stimulated turnover in brain and neuroblastomas, in which evidence is obtained for the breakdown of $\mathrm{PIP}_{2}$ and/or PIP, but not of PI (Batty and Nahorski, 1989; Fisher et al., 1990). The second property of note is that the concentration of $\mathrm{Ca}^{2+}$ required for full activation of $\mathrm{PIP}_{2}$ hydrolysis is within the physiological range $(0.1-1.0 \mu M)$, whereas much higher concentrations of the cation are required for PI hydrolysis. Thus, PLC is regulated by physiologically relevant concentrations of $\mathrm{Ca}^{2+}$, an observation consistent with the ability of agents which promote a rise in the concentration of intracellular $\mathrm{Ca}^{2+}$ $\left(\left[\mathrm{Ca}^{2+}\right]_{\mathrm{i}}\right)$, such as $\mathrm{K}^{+}$depolarization, $\mathrm{Ca}^{2+}$ ionophores, or maitotoxin, to elicit an increased phosphoinositide hydrolysis in neural tissues (Eberhard and Holz, 1988; Gusovsky et al., 1989; Baird and Nahorski, 1990a). In digitonin-permeabilized neuroblastoma cells, PLC activity could be regulated by alterations in $\left[\mathrm{Ca}^{2+}\right]_{i}$ (Fisher et al., 1989).

It has been calculated that the activity of brain PLC, if unregulated, would be sufficient to elicit complete hydrolysis of $\mathrm{PIP}_{2}$ within 2-20 s, even in the absence of receptor activation (Rhee et al., 1989). Although such calculations ignore $\mathrm{PIP}_{2}$ resynthesis, it is probable that PLC activity in vivo is subject to stringent control. A further consideration is that the breakdown and resynthesis of $\mathrm{PIP}_{2}$ is metabolically expensive $(3 \mathrm{~mol}$ of ATP and $1 \mathrm{~mol}$ of CTP consumed per mol of PIP hydrolyzed). These observations have led to the (as yet unconfirmed) suggestion that a regulatory protein exists which represses PLC in vivo (Fain et al., 1988; Rhee et al., 1989). More definite evidence exists for the ability of guanine nucleotide binding protein(s) [G protein(s)] to regulate PLC activity. The activation of PLC by guanine nucleotides (Gonzales and Crews, 1985) is presumably mediated through $G$ protein $\left(G_{p}\right)$ which in neural, as in nonneural tissues, is usually insensitive to either pertussis or cholera toxins. A novel pertussis toxin-insensitive $G$ protein, $G_{q}$, has been shown recently to activate specifically the $\beta$ isozyme of PLC from bovine brain (Smrcka et al., 1991; Taylor et al., 1991). More elusive has been the demonstration of GTP-dependent agonist-stimulated PLC activity in brain membranes, but such has been observed recently (Chiu et al., 1988; Claró et al., 1989; Carter et al., $1990 a$ ). Whereas carbachol alone elicits little or no activation of PLC, a potentiative interaction occurs in the presence of guanosine $5^{\prime}-O$-(3-thiotriphosphate) $(\mathrm{GTP} \gamma \mathrm{S})$. Inhibitory G proteins may also regulate PLC. Nanomolar concentrations of nonhydrolyzable GTP analogues inhibit basal PLC activity, whereas at higher concentrations of the guanine nucleotide $(>1 \mu M)$, the predicted stimulation of enzyme activity occurs ( $\mathrm{Li}-$ tosch, 1989). The inhibitory (but not the stimulatory) effect on PLC activity can be prevented by preincubation of the membranes with pertussis toxin. Addition of $\mathrm{F}^{-}$is also able to activate phosphoinositide hydrolysis in membranes, an effect usually attributed to activation of $\mathrm{G}_{\mathrm{p}}$ (Litosch, 1987; Godfrey and Watson 1988; Gonzales and Crews, 1988; Jope, 1988). However, some caution is warranted in this interpretation, because the $\mathrm{F}^{-}$effect on inositol phosphate release is not blocked by guanosine $5^{\prime}-\mathrm{O}$-(2-thiodiphosphate) (P. P. Li et al., 1990). Furthermore, $F^{-}$has been demonstrated to activate purified PLC- $\beta$ directly (Carter et al., 1990b). The mechanism whereby $G_{p}$ activation regulates PLC activity is still uncertain, but may be a lowering of the enzyme's requirement for $\mathrm{Ca}^{2+}$. Thus, in the absence of guanine nucleotides, supraphysiological concentrations of $\mathrm{Ca}^{2+}(1-10 \mu M)$ are needed for enzyme activation in permeabilized neuroblastoma cells, whereas in the presence of GTP $\gamma \mathrm{S}$, concentrations of $\mathrm{Ca}^{2+}$ found in the cytosol of these cells $(30-150 \mathrm{nM})$ suffice (Fisher et al., 1989).

PLC may also be regulated through phosphorylation. Numerous reports exist to indicate that activation of PKC by phorbol esters results in an inhibition of receptor-activated phosphoinositide hydrolysis (see Fisher and Agranoff, 1987, and references therein; Orellana et al., 1987; Pearce et al., 1988), and studies with permeabilized cells indicate that this inhibition resides at, or distal to, the $\mathrm{G}_{\mathrm{p}}$-PLC interaction site (Orellana et al., 1987; Cioffi and Fisher, 1990). Direct phosphorylation of PLC- $\alpha,-\beta,-\gamma$, and $-\delta$ has been demonstrated in vitro upon the addition of purified PKC (Crooke and Bennett, 1989). However, no change in the catalytic activity of PLC occurs under such conditions. This raises the possibilities that PLC itself is not the target for PKC-mediated phosphorylation or, alternatively, that phosphorylated PLC loses its ability to interact with $G_{p}$. Phosphorylation of PLC by protein kinase A (PKA) also remains a possibility. Increases in tissue cyclic AMP are accompanied by an inhibition of both receptor- and GTP $\gamma$ S-stimulated phosphoinositide turnover in neuroblastoma and glioma cells, primary glial cultures, and isolated membranes (Akil and Fisher, 1989; Kim et al., 1989; Campbell et al., 1990; McAtee and Dawson, 1990; Robertson et al., 1990). It is suggested that the site of inhibition is at, or is distal 
to, the $\mathrm{G}_{\mathrm{p}}-\mathrm{PLC}$ interaction (Akil and Fisher, 1989; McAtee and Dawson, 1990; Robertson et al., 1990), in a manner analogous to that observed for PKC inhibition. There is also evidence from nonneural cells that PLC is phosphorylated in response to the addition of growth factors. The latter bind to receptors which possess intrinsic tyrosine kinase activity, which can then phosphorylate a tyrosine residue on the PLC- $\gamma$ (Rhee et al., 1989, and references therein). This means of receptor-activated PLC activity can be distinguished from the aforementioned types in that an intervening G protein is not involved (Boyer et al., 1989). Rhee et al. (1989) note that the molecular masses of PLC are significantly larger than those of related enzymes [e.g., phospholipase $\mathrm{A}_{2}\left(\mathrm{PLA}_{2}\right)$ ], lending support to their suggestion that large portions of the PLC molecule are devoted to the enzyme's regulation.

Few specific inhibitors of PLC are currently available. Manoalide, which causes the irreversible inactivation of PLC- $\alpha$, also has other sites of action, such as the blockade of $\mathrm{Ca}^{2+}$ channels and inhibition of $\mathrm{PLA}_{2}$ (Crooke and Bennett, 1989). Mastoparan, a wasp venom undecapeptide, blocks GTP $\gamma$ S-stimulated phosphoinositide turnover in neuroblastoma and astrocytoma cells (Wojcikiewicz and Nahorski, 1989; Nakahata et al., 1990). This compound does not penetrate intact cells uniformly, it is not specific for $G_{p}$ linked receptors, and its mode of inhibition (i.e., through $G_{p}$ or direct interaction with PIP $_{2}$ ) is uncertain. To date, the most promising agent is the aminosteroid U-73122. This agent readily gains access to intact cells and blocks stimulated inositol lipid turnover, $\mathrm{Ca}^{2+}$ signaling, and related events (Bleasdale et al., 1990; Smith et al., 1990; Thompson et al., 1991). It is particularly effective at blocking GTP $\gamma$ S-stimulated phosphoinositide turnover, whereas that induced by the addition of $\mathrm{Ca}^{2+}$ is less affected.

\section{INOSITOL PHOSPHATE ISOMER FORMATION, METABOLISM, AND FUNCTION}

\section{Metabolism of $\mathbf{I}(1,4,5) \mathrm{P}_{3}$}

The complexity of the metabolism of the inositol phosphates has become increasingly evident with the identification in tissues of more than 20 of the 63 possible isomers. Much effort has been expended in the elucidation of both their metabolic interrelationships and the characteristics of the relevant enzymes involved (for review, see Shears, 1989). It is now generally accepted that in brain, as in other tissues, the initial product of receptor-stimulated PLC activity is $\mathbf{I}(1,4,5) \mathbf{P}_{3}$ (and possibly its cyclic 1,2 derivative). Because it has been established that $\mathrm{IP}_{3}$ acts as a second messenger in the mobilization of intracellular $\mathrm{Ca}^{2+}$, the routes of its enzymatic metabolism and their regulation assume considerable importance (see Fig. 1). I( $1,4,5) \mathbf{P}_{3}$ can be metabolized by either 5-phosphatase or 3-kinase activities to yield inositol 1,4-bisphosphate $\left[\mathbf{I}(1,4) \mathrm{P}_{2}\right]$ or inositol 1,3,4,5-tetrakisphosphate $\left[\mathrm{I}(1,3,4,5) \mathrm{P}_{4}\right]$, respectively, either of which could be regarded as "off" signals. The 5-phosphatase is particularly enriched in cerebellum $(50-60 \%$ of total brain activity) and has been localized histochemically to the cerebellar molecular layer (Heacock et al., 1990). Although primarily particulate (Erneux et al., 1986), two forms of the 5phosphatase have been purified from brain cytosol (Hansen et al., 1987). Both type I (60 kDa) and type II ( $160 \mathrm{kDa})$ attack $\mathrm{I}(1,4,5) \mathrm{P}_{3}$ and $\mathrm{I}(1,3,4,5) \mathrm{P}_{4}$, although the type II enzyme is relatively weak against the latter substrate. With $\mathrm{I}(1,4,5) \mathrm{P}_{3}$ as substrate, the $\mathrm{I}(1,4) \mathrm{P}_{2}$ that results from 5-phosphatase action is dephosphorylated further to inositol 4-monophosphate [I(4) $\left.\mathrm{P}_{1}\right]$ via the action of a $\mathrm{Mg}^{2+}$-dependent inositol polyphosphate 1phosphatase (Inhorn and Majerus, 1987, 1988; Gee et al., 1988a). This enzyme has been purified from brain cytosol, has an $M_{r}$ of $40 \mathrm{~K}-44 \mathrm{~K}$, and is inhibited by $\mathrm{Ca}^{2+}$, and uncompetitively by $\mathrm{Li}^{+}$. 4-Phosphatase activity against $\mathrm{I}(1,4) \mathrm{P}_{2}$ in various tissue homogenates, including brain (Ackermann et al., 1987; Ragan et al., 1988) and neuroblastoma (Fisher et al., 1990), is either absent or low.

Alternatively, $I(1,4,5) \mathrm{P}_{3}$ may be converted to $\mathrm{I}(1,3,4,5) \mathrm{P}_{4}$ via $\mathrm{IP}_{3}$ kinase. In contrast to the 5-phosphatase, the 3-kinase is largely cytosolic and is particularly enriched in cortex, cerebellum, and hippocampus (Heacock et al., 1990). Recent in situ hybridization studies indicate a preponderance of the enzyme's mRNA in CA1 pyramidal neurons, granule cells of the dentate gyrus, and cerebellar Purkinje cells (Mailleux et al., 1991). The kinase has been purified from brain (Johanson et al., 1988; Lee et al., 1990; Takazawa et al., 1990a), and its cDNA has been cloned and sequenced (Choi et al., 1990; Takazawa et al., 1990b). The predicted molecular mass $(50 \mathrm{kDa})$ is in close agreement with values obtained for the protein on sodium dodecyl sulfate-polyacrylamide gel electrophoresis (SDS-PAGE). $\mathrm{Ca}^{2+}$ and calmodulin increase the $V_{\max }$ of the enzyme at $\mathrm{IP}_{3}$ concentrations greater than the $K_{\mathrm{m}}$ (Johanson et al., 1988; Takazawa et al., 1988; Heacock et al., 1990). A rise in $\left[\mathrm{Ca}^{2+}\right]_{\mathrm{i}}$ may thus promote the formation of $\mathrm{I}(1,3,4,5) \mathrm{P}_{4}$, which is itself implicated in $\mathrm{Ca}^{2+}$ homeostasis. In addition to possessing a calmodulin-binding site, $\mathrm{IP}_{3}$ kinase also exhibits six regions enriched in sequences that contain five amino acids (proline, glutamate, aspartate, serine, and threonine) which render it susceptible to hydrolysis by the protease calpain (Choi et al., 1990). A further potential means of regulation is via phosphorylation of the enzyme. Sim et al. (1990) have demonstrated that PKAand $\mathrm{PKC}$-induced phosphorylations of serine residues on brain $\mathrm{IP}_{3}$ kinase increase and decrease, respectively, the $V_{\max }$ of enzyme activity.

Once formed, the major route of $\mathrm{I}(1,3,4,5) \mathrm{P}_{4}$ metabolism is that of dephosphorylation to $\mathrm{I}(1,3,4) \mathrm{P}_{3}$, catalyzed by the same 5 -phosphatase that acts on $\mathbf{I}(1,4,5) \mathbf{P}_{3}$. In addition, an $\mathbf{I}(1,3,4,5) \mathbf{P}_{4}$ 3-phosphatase activity has been found in brain cytosol, which results 


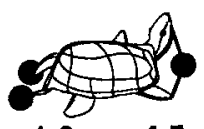

1:2-cyc 4,5

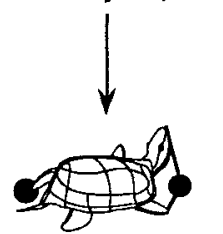

1:2-cyc 4

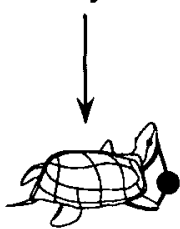
1:2-cyc
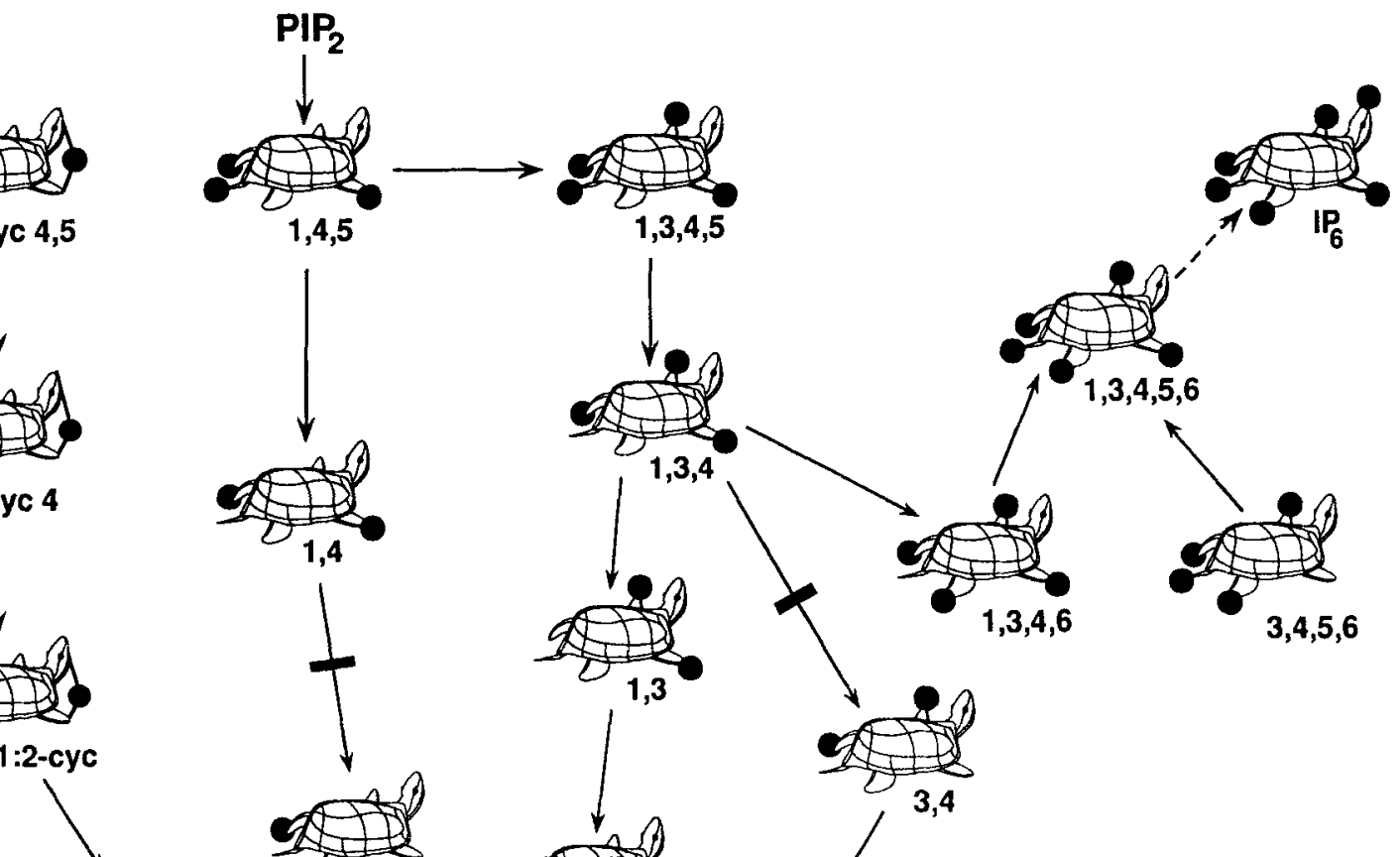

,

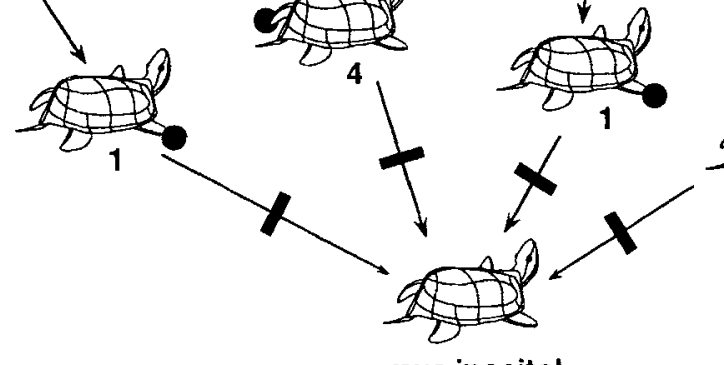

myo-inositol

FIG. 1. Pathways of $I(1,4,5) P_{3}$ metabolism in neural tissues. myo-Inositol is visualized as a turtle in which the axial (2) position is the head and the five equatorial hydroxyls constitute the four legs and tail (Agranoff, 1978). The solid spheres indicate the positions of the phosphate groups. See text for details of enzymatic conversions. The dashed line indicates a pathway that is yet to be demonstrated in CNS. It is also possibie that an initial product of $\mathrm{PIP}_{2}$ hydrolysis is the cyclic 1,2 derivative of $\mathrm{IP}_{3}$. This inositol phosphate is presumed to undergo sequential dephosphorylations to (cyclic 1,2$) I P_{1}$, then $1(1) P_{1}$, and thence to myo-inositol. The dephosphorylation of $I(1,3) P_{2}$ to $I(3) P_{1}$ has yet to be described. Also not shown is an alternative pathway for $\mathrm{IP}_{6}$ formation (see text). The solid bars indicate enzymatic steps subject to $\mathrm{Li}^{+}$inhibition.

in the reformation of $\mathrm{I}(1,4,5) \mathrm{P}_{3}$ (Höer et al., 1988, 1990). The physiological significance of a 3-kinase/3phosphatase futile cycle has been questioned (Downes and MacPhee, 1990). $\mathrm{I}(1,3,4) \mathrm{P}_{3}$ is acted upon either by inositol polyphosphate 1-phosphatase (Inhorn and Majerus, 1987, 1988; Gee et al., 1988a) to produce $\mathrm{I}(3,4) \mathrm{P}_{2}$ or, alternatively, by a $\mathrm{Li}^{+}$-insensitive 4-phosphatase to yield $I(1,3) P_{2}$. These two compounds are then dephosphorylated further by 4- or 3-phosphatases to yield $\mathrm{I}(3) \mathrm{P}_{1}$ and $\mathrm{I}(1) \mathrm{P}_{1}$, respectively. Whereas the 4phosphatase is insensitive to both $\mathrm{Li}^{+}$and $\mathrm{Mg}^{2+}$, two separate 3-phosphatase activities can be distinguished by their $\mathrm{Mg}^{2+}$ requirements (Howell et al., 1989). As was originally proposed (Ackermann et al., 1987), a single enzyme, inositol monophosphatase, exhibits similar affinities for the dephosphorylation of $\mathrm{I}(1) \mathrm{P}_{1}$ and $\mathrm{I}(4) \mathrm{P}_{1}$ and, most likely, for other $\mathrm{IP}_{1}$ isomers (Shears, 1989). The enzyme, which has been purified to homogeneity (Gee et al., 1988b; Meek et al., 1988), exists as a dimer of subunit $\mathrm{M}_{\mathrm{r}} 29 \mathrm{~K}$ and is inhibited by $\mathrm{Li}^{+}$in an uncompetitive manner with a $K_{\mathrm{i}}$ of $<1$ $\mathrm{m} M$. The cDNA for the enzyme, which has been cloned, sequenced, and expressed, encodes a protein of 277 amino acids with an $\mathrm{M}_{\mathrm{r}}$ of $\sim 30 \mathrm{~K}$ (Diehl et al., 1990). Unlike many other tissues, brain can synthesize inositol de novo (Eisenberg, 1967). The key enzyme, IP ${ }_{1}$ synthase, which catalyzes the cyclization of glucose 6-phosphate, has been localized immunohistochemically to the brain vasculature (Wong et al., 1987).

As yet, relatively little is known of the pathways of synthesis for inositol pentakisphosphate $\left(\mathrm{IP}_{5}\right)$ and inositol hexakisphosphate $\left(\mathrm{IP}_{6}\right)$ in neural tissues. These assume importance in view of the recent observation that the addition of either high $\mathrm{K}^{+}$or agonists elicits an increase in $\mathrm{IP}_{5}$ formation in chromaffin cells (Sasakawa et al., 1990). In homogenates of both brain (Stephens et al., 1988) and chromaffin cells (Sasakawa et al., 1990), added $\left[{ }^{3} \mathrm{H}\right] \mathrm{I}(1,4,5) \mathrm{P}_{3}$ can be converted to 
$\left[{ }^{3} \mathrm{H}\right] \mathrm{IP} \mathrm{P}_{5}$. In brain, the $\mathrm{I}(1,3,4,5,6) \mathrm{P}_{5}$ isomer has been shown to be synthesized from $I(1,3,4,6) P_{4}$, which in turn is formed from kinase action on $\mathrm{I}(1,3,4) \mathrm{P}_{3}$ (Stephens et al., 1988). In a preliminary study, evidence was provided for the presence in brain cytosol of an additional kinase which preferentially phosphorylates $\mathrm{IP}_{5}$ (Stanley et al., 1990). However, the enzyme appears to be specific for the $1,2,4,5,6$ isomer, rather than $\mathrm{I}(1,3,4,5,6) \mathrm{P}_{5}$.

Although a principal function of the complex series of metabolic reactions that inactivates $I_{3}$ seems to be to replenish the intracellular inositol pool, the possibility must also be considered that some of the intermediates formed may be physiologically relevant. In this context, $\mathrm{I}(1,4) \mathrm{P}_{2}$ has been reported to activate DNA polymerase (Sylvia et al., 1988). Although roles in cellular functions have been proposed for the higher inositol phosphates $\left(\mathrm{IP}_{4}, \mathrm{IP}_{5}\right.$, and $\left.\mathrm{IP}_{6}\right)$, at present, the only inositol phosphate that has been linked definitively to cellular signaling events is $\mathrm{I}(1,4,5) \mathrm{P}_{3}$.

\section{$\mathrm{I}(1,4,5) \mathrm{P}_{3}$ receptors and $\mathrm{Ca}^{2+}$ homeostasis}

The direct injection of $\mathrm{I}(1,4,5) \mathrm{P}_{3}$ into cells, or its addition to permeabilized cells or membrane fractions, elicits an increase in $\mathrm{Ca}^{2+}$ release from nonmitochondrial stores in both neural and nonneural tissues. The release is specific for the $\mathrm{D}$ isomer, is unaffected by known $\mathrm{Ca}^{2+}$-channel blockers, requires the presence of $\mathrm{K}^{+}$, and can occur at low temperatures (for reviews, see Berridge and Irvine, 1989; Joseph and Williamson, 1989; Nahorski and Potter, 1989). That these effects of $\mathrm{I}(1,4,5) \mathrm{P}_{3}$ on $\mathrm{Ca}^{2+}$ release are likely mediated through the action of specific intracellular receptor sites was recognized some time ago. The first direct demonstration of such sites (albeit in low density) was made in liver and neutrophils by Spät et al. (1986). A detailed distribution of $I(1,4,5) P_{3}$ binding sites in brain has been obtained by means of both receptor autoradiography (Worley et al., 1987a, 1989) and radioligand binding assays (Worley et al., 1987b). Moderate levels of binding sites are present in the hippocampus, cerebral cortex, caudate nucleus, and substantia nigra, whereas the highest concentrations by far are found in the cerebellum (Purkinje cell layer). Their enrichment in the cerebellum has greatly facilitated progress in the elucidation of the molecular characteristics of the $\mathrm{I}(1,4,5) \mathrm{P}_{3}$ receptor. When assayed at $4^{\circ} \mathrm{C}$ and in the absence of $\mathrm{Mg}^{2+}$ (to avoid ligand degradation), the binding of $\left[{ }^{3} \mathrm{H}\right] \mathrm{I}(1,4,5) \mathrm{P}_{3}$ to cerebellar membranes is saturable $\left(K_{\mathrm{D}}=80-100 \mathrm{n} M\right)$ and highly stereospecific. Because intracellular concentrations of $\mathrm{I}(1,4,5) \mathrm{P}_{3}$ in brain are reportedly at least 10 -fold higher than this $K_{\mathrm{D}}$ value (Challis et al., 1988), the concept of compartmentation of $\mathrm{I}(1,4,5) \mathrm{P}_{3}$ has been invoked (Challis et al., 1990). Heparin is a potent antagonist, and inclusion of $\mathrm{Ca}^{2+}$ at physiological concentrations $(1 \mu M)$ inhibits binding. The ability of heparin to bind the $\mathrm{IP}_{3}$ receptor has been used to advantage in purification of the $\mathrm{IP}_{3}$ receptor (Supattapone et al., 1988). The receptor has an $\mathrm{M}_{\mathrm{r}}$ of $260 \mathrm{~K}$ on SDS-PAGE and is highly selective for $I(1,4,5) P_{3}$. Ligand binding to the purified receptor is insensitive to $\mathrm{Ca}^{2+}$, but $\mathrm{Ca}^{2+}$ sensitivity is restored by the addition of detergent-solubilized cerebellar membranes. Danoff et al. (1988) subsequently established the presence in these extracts of a protein named "calmedin," which exhibited an $\mathrm{M}_{\mathrm{r}}$ of $300 \mathrm{~K}$ on gel filtration and which conferred $\mathrm{Ca}^{2+}$ sensitivity on the purified receptor. Calmedin is abundant in neural tissues, in keeping with the observation that $\mathrm{Ca}^{2+}$ sensitivity of $\mathrm{I}(1,4,5) \mathrm{P}_{3}$ binding is prevalent in CNS. Although differences in $\mathrm{Ca}^{2+}$ sensitivity and in $K_{\mathrm{D}}$ values of $\mathrm{I}(1,4,5) \mathrm{P}_{3}$ binding might indicate the existence of multiple receptor subtypes, studies which directly address the issue have not previously supported this proposition (Nunn et al., 1990; Varney et al., 1990). However, Danoff et al. (1991) have recently identified distinct neuronal and nonneuronal forms of the $\mathrm{I}(1,4,5) \mathrm{P}_{3}$ receptor that are formed by alternative splicing. The longer transcript corresponds to the neuronal form of the receptor which contains a 120-nucleotide insert (absent from the nonneuronal receptor) located between two PKA phosphorylation consensus sequences.

In retrospect, the $\mathrm{IP}_{3}$ receptor had been first encountered, in fact, some 12 years earlier by Mallet et al. (1976) who, in a study of cerebellar ataxic mice, observed that a membrane glycoprotein $\left(\mathrm{P}_{400}\right)$ was enriched in Purkinje cells of normal mice, but was reduced in Purkinje cell-deficient mutants. As noted for the $\mathrm{IP}_{3}$ receptor, $\mathrm{P}_{400}$ is a glycoprotein of $\mathrm{M}_{\mathrm{r}} 250 \mathrm{~K}$ on SDS-PAGE and is highly enriched in the cerebellum. The availability of monoclonal antibodies permitted the cloning of cDNA for $\mathrm{P}_{400}$ and determination of its amino acid sequence (Furuichi et al., 1989). On the basis of its cDNA sequence, $P_{400}$ is comprised of 2,749 amino acids with an $M_{r}$ of $313 \mathrm{~K}$, a value greater than that obtained on SDS-PAGE. This discrepancy may be due to either an aberrant electrophoretic migration of the protein or posttranslational proteolytic processing. Mignery et al. (1990) independently obtained the complete primary structure for the $\mathrm{IP}_{3}$ receptor in rat cerebellum using a series of overlapping cDNA clones that encode for proteins which contain either 2,734 or 2,749 amino acids. Only 21 amino acid substitutions were observed when the rat receptor sequence was compared with that of murine $\mathrm{P}_{400}$. Furthermore, purified $\mathbf{P}_{400}$ bound $\left[{ }^{3} \mathrm{H}\right] \mathrm{I}(1,4,5) \mathrm{P}_{3}$ in a saturable and specific manner analogous to that observed for the purified $\mathrm{IP}_{3}$ receptor (Maeda et al., 1990). Confirmation that $\mathrm{P}_{400}$ and the $\mathrm{IP}_{3}$ receptor are one and the same was obtained from experiments in which transfection of $P_{400}$ cDNA into NG108-15 cells resulted in the expression of IP-binding sites (Furuichi et al., 1989). The $\mathrm{IP}_{3}$ receptor is not identical to the ryanodine receptor, but shares considerable homology with it (Mignery et al., 1989).

There is less agreement regarding the subcellular localization of the receptor. Using monoclonal antibodies 
to $P_{400}$, Maeda et al. (1989) observed that the receptor was localized to the endoplasmic reticulum, plasma membrane, and postsynaptic density. In contrast, using polyclonal antibodies, Ross et al. (1989) localized the $\mathrm{IP}_{3}$ receptor to the endoplasmic reticulum, the subplasmalemmal cisternae, and nuclear membrane, but not to the plasma membrane. Two further studies in which an immunogold labeling technique was employed also failed to detect $\mathrm{IP}_{3}$ receptors at the plasma membrane (Mignery et al., 1989; Satoh et al., 1990). It appears then that $\mathrm{IP}_{3}$ receptors are associated predominantly, if not exclusively, with the smooth endoplasmic reticulum.

$\mathrm{IP}_{3}$ receptors may be regulated in vivo by both ATP and cyclic AMP, in addition to $\mathrm{Ca}^{2+}$. When reconstituted into either lipid vesicles or a planar lipid bilayer, the $\mathrm{IP}_{3}$ receptor mediates an increase in $\mathrm{Ca}^{2+}$ flux (Ferris et al., 1989; Maeda et al., 1991). Submillimolar concentrations of ATP increase this flux following interaction of the nucleotide with an ATP-binding site (Ferris et al., 1990; Maeda et al., 1991), whereas higher concentrations (millimolar) inhibit $\mathrm{Ca}^{2+}$ flux, consistent with the reported inhibitory effects of ATP on $\left[{ }^{3} \mathrm{H}\right] \mathrm{I}(1,4,5) \mathbf{P}_{3}$ binding (Willcocks et al., 1987). The IP ${ }_{3}$ receptor also contains three consensus amino acid sequences that fulfill the criteria for PKA action (Mignery et al., 1990). Addition of PKA catalytic subunits to cerebellar microsomes markedly reduces the potency with which $\mathrm{IP}_{3}$ enhances ${ }^{45} \mathrm{Ca}^{2+}$ release (Snyder and Supattapone, 1989).

The native $\mathrm{IP}_{3}$ receptor is thought to be a tetramer, composed of four noncovalently bound identical subunits of $\mathrm{M}_{\mathrm{r}} \sim 300 \mathrm{~K}$, each subunit possessing an independent ligand binding site (Mignery et al., 1990; Maeda et al., 1991). It is proposed that the tetramer forms a single central transmembrane pore. Upon the binding of three to four molecules of $\mathrm{IP}_{3}$ (Meyer et al., 1988), a conformational change in the receptor occurs and an open ion channel forms (Maeda et al., 1991). The $\mathrm{Ca}^{2+}$ signal so generated is frequently found to oscillate in single cells. Whether such oscillations reflect cyclical changes in $\mathrm{IP}_{3}$ mass or, alternatively, that a constant concentration of $\mathrm{IP}_{3}$ drives intracellular $\mathrm{Ca}^{2+}$ oscillations is currently under investigation (Wakui et al., 1989; Harootunian et al., 1991).

\section{Higher inositol phosphates}

Although there has been much speculation over the possible involvement of $\mathrm{IP}_{4}$ in the maintenance of a prolonged receptor-mediated $\mathrm{Ca}^{2+}$ signal in nonneural tissues, there is little direct evidence for a similar role in the CNS. However, it should be stressed that $\mathbf{I}(1,3,4,5) \mathrm{P}_{4}$ is formed readily upon receptor activation in brain slices, during which time its concentration may rise 20-fold (Challis and Nahorski, 1990). Furthermore, specific $\mathrm{I}(1,3,4,5) \mathrm{P}_{4}$ binding sites in cerebellum have been purified 1,000-fold from homogenates (Donié et al., 1990). In oocytes, $I(1,3,4,5) \mathrm{P}_{4}$ and $\mathrm{I}(1,3,4,6) \mathrm{P}_{4}$ (both of which can be formed in brain) are effective in altering
$\mathrm{Ca}^{2+}$ homeostasis (Ivorra et al., 1991). For further discussion of the possible role of $\mathrm{IP}_{4}$, the reader is referred to reviews by Joseph and Williamson (1989), Nahorski and Potter (1989), and Downes and MacPhee (1990).

In contrast to the intracellular roles envisioned for $\mathrm{IP}_{3}$ and $\mathrm{IP}_{4}$, an extracellular role has been proposed for IP 5 and IP $_{6}$ by Vallejo et al. (1987) based upon the ability of these inositol phosphates to elicit changes in heart rate and blood pressure when injected into the nucleus tractus solitarius. Bath application of $\mathrm{IP}_{6}$ to slices of rat brainstem failed, however, to alter the excitability, membrane potential, or resistance at concentrations of $44 \mu M$ (Brooks and Spyer, 1989). Nonetheless, demonstration of specific $\mathrm{IP}_{6}$ binding sites in both brain and pituitary, and their linkage to ${ }^{45} \mathrm{Ca}^{2+}$ flux in the latter tissue, leave open the possibility of an extracellular role for these inositol polyphosphates (Hawkins et al., 1990; Nicoletti et al., 1990; Sortino et al., 1990).

\section{RECEPTOR SUBTYPES COUPLED TO PHOSPHOINOSITIDE TURNOVER}

More than 25 pharmacologically distinct receptors present on neurons and/or glia have been linked thus far to phosphoinositide turnover. Whereas an impressive number of receptors are now purported to couple to inositol lipid hydrolysis, two groups can still be clearly distinguished. Activation of category I receptors elicits a robust increase in inositol lipid turnover in tissue preparations obtained from both the CNS (brain slices, primary neuronal and glial cultures) and neurotumor cells. For a second group (category II), receptor activation elicits only small increases in inositol lipid turnover in CNS-derived preparations, such that most of the evidence accumulated in favor of their involvement has been obtained not from brain, but from the use of neurotumor cells or other neural-related tissues. A comprehensive list of receptor subtype(s) known to be linked to phosphoinositide turnover is shown in Table 3. Discussion below is restricted to newly identified receptors (or subtypes) for which substantive information exists and to previously unrecognized aspects of receptor function.

\section{Category I}

Muscarinic cholinergic. The previous division of muscarinic acetylcholine receptors ( $\mathrm{mAChRs}$ ) into two groups $\left(M_{1}\right.$ and $\left.M_{2}\right)$ based on pirenzepine sensitivity is now superseded by molecular cloning studies. At least five biochemically and pharmacologically distinct subtypes of mAChRs are known (Bonner et al., 1987, 1988). Transfection studies with cDNAs encoding individual $m A C h R$ subtypes have indicated that $M_{1}, M_{3}$, and $\mathrm{M}_{5}$ receptors couple primarily to phosphoinositide turnover, whereas the $\mathrm{M}_{2}$ and $\mathrm{M}_{4}$ subtypes are linked to inhibition of adenylate cyclase (Bonner et al., 1988; Ashkenazi et al., 1989). $M_{1}$ and $M_{3}$ mAChRs can be 
TABLE 3. Receptor activation of phosphoinositide turnover in neural tissues

\section{CATEGORY 1}

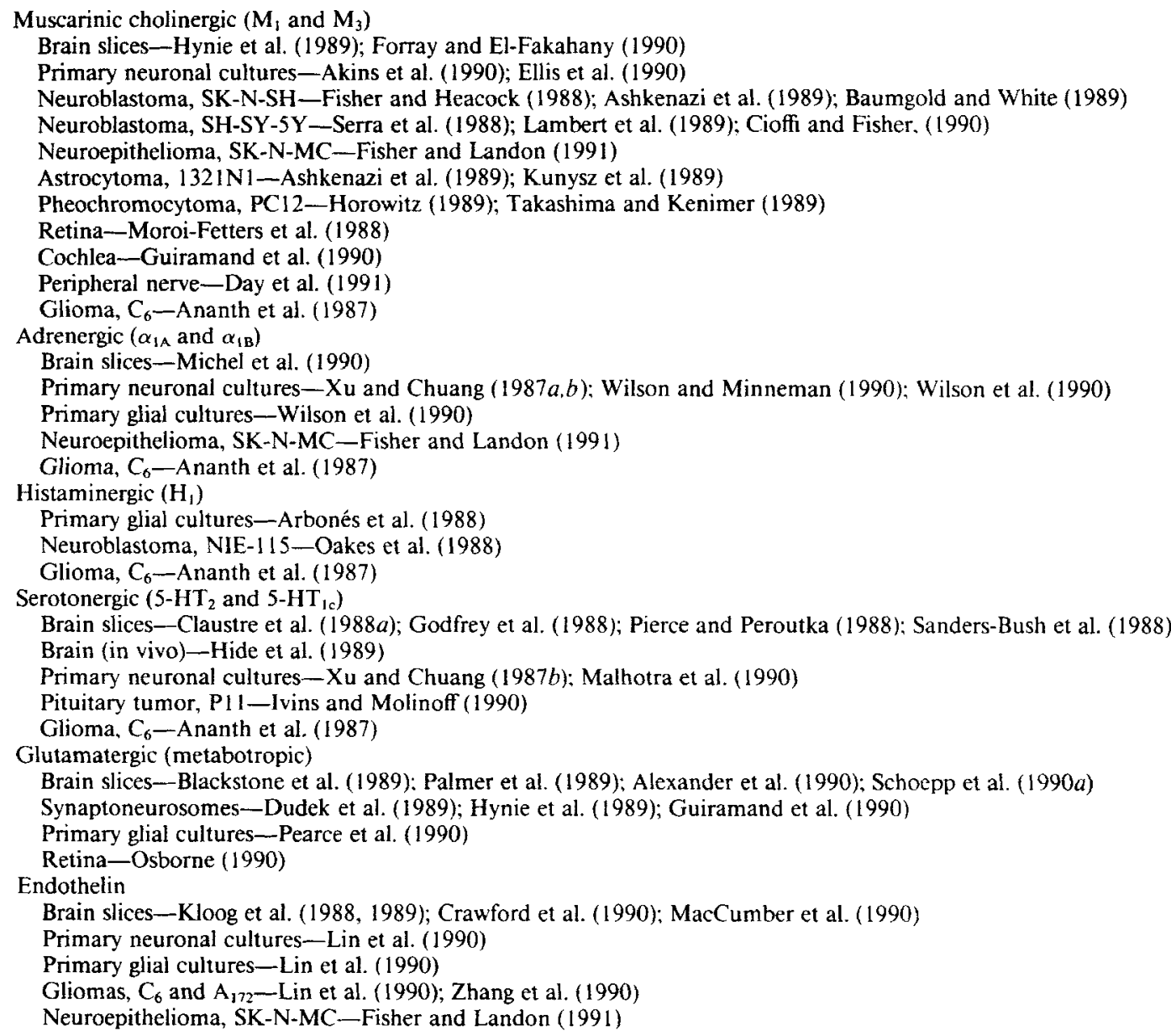

\section{CATEGORY II}

Purinergic $\left(\mathbf{P}_{2}\right)$

Primary glial cultures-Pearce et al. (1990)

Neuroblastoma, NIE-1 I5-Ehrlich et al. (1988)

Neuroepithelioma, SK-N-MC-Fisher and Landon (1991)

Adrenal medulla-Sasakawa et al. (1989); Allsup and Boarder (1990)

Pituitary--Van der Merwe et al. (1989); Davidson et al. (1990)

Thromboxane $\left(\mathrm{A}_{2}\right)$

Astrocytoma, 1321N1-Nakahata et al. (1989)

Nerve growth factor

Pheochromocytoma, PC12-Volonté and Racker (1988); Volonté et al. (1988); Van Calker et al. (1989)

Prostaglandin $\left(\mathrm{E}_{2}\right)$

Adrenal medulla-Negishi et al. (1989)

Bradykinin $\left(\mathrm{B}_{2}\right)$

Primary glial cultures-Cholewinski et al. (1988)

Dorsal root ganglion-Burgess et al. (1989); Gammon et al (1989); Perney and Miller (1989);

Neuroblastoma-glioma NG108-15-Chiang and Hauser (1989); Imaizumi et al. (1989)

Pheochromocytoma, PC12-Volonté et al. (1988)

Neurohybridoma, NCB-20-Chuang and Dillon-Carter (1988)

Pituitary tumor, Flow 9000-Sharif et al. (1988)

Anterior pituitary-T. H. Jones et al. (1989)

Vasopressin $\left(\mathrm{V}_{1}\right)$

Brain slices-Moratalla et al. (1988); Shewey and Dorsa (1988)

Primary glial cultures-Cholewinski et al. (1988) 
TABLE 3-Continued

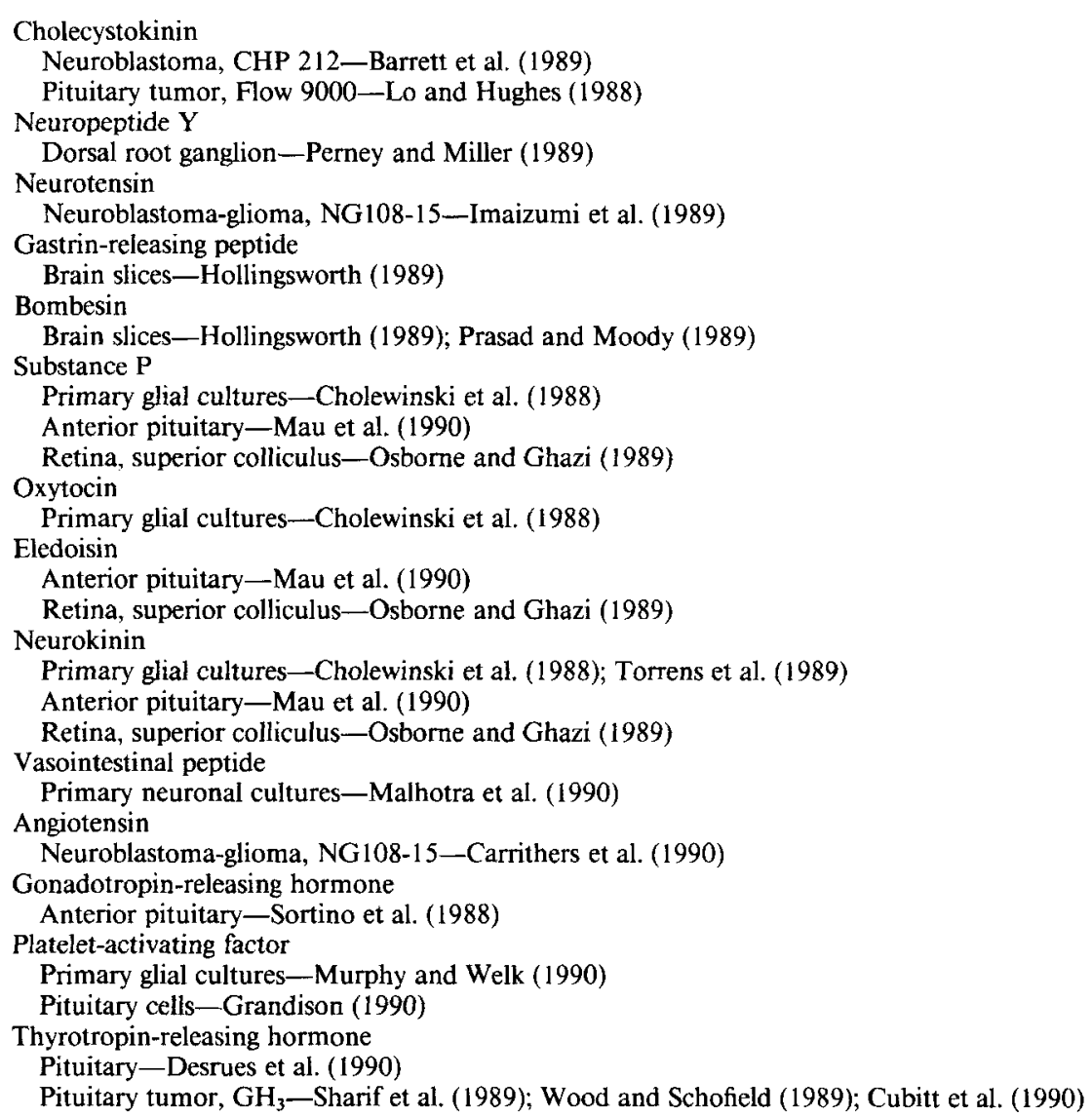

distinguished on the basis of their pirenzepine sensitivities $\left(M_{1}>M_{3}\right)$ and their $M_{r}$ values $\left(M_{3}>M_{1}\right)$. Whereas the involvement of the $M_{1}$ subtype in phosphoinositide hydrolysis had been firmly established previously, it has since been shown that the $\mathrm{M}_{3}$ receptor is also functionally linked. $\mathrm{mAChRs}$ present on both SK-N-SH neuroblastoma and 132 INI astrocytoma cells exhibit a higher $M_{r}(90 \mathrm{~K}-100 \mathrm{~K})$ than that associated with the $M_{1}$ subtype $(60 \mathrm{~K}-70 \mathrm{~K})$, and pirenzepine only weakly inhibits the ability of these $M_{3}$ receptors to activate inositol lipid hydrolysis (Liang et al., 1987; Fisher and Heacock, 1988; Baumgold and White, 1989; Kunysz et al., 1989). For the SH-SY-5Y cell line, a neuroblast subclone of the SK-N-SH cell, there is conflicting evidence as to the predominant subtype present. From both pharmacological and biochemical considerations (Lambert et al., 1989; Cioffi and Fisher, 1990), it has been concluded that these cells also express the $\mathrm{M}_{3}$ subtype. In contrast, the results of Serra et al. (1988), obtained with the same cells, are more consistent with the presence of a functionally linked $M_{1}$ receptor. Additional pharmacological evidence for the involvement of $\mathrm{M}_{3}$ receptors in phosphoinositide hydrolysis has been obtained recently for both primary neuronal cultures (Ellis et al., 1990) and brain slices (Forray and El-Fakahany, 1990).

A characteristic of $\mathrm{mAChR}$-stimulated phosphoinositide hydrolysis in a variety of neural preparations is its slow rate of desensitization (Nakahata and Harden, 1987; Xu and Chuang, 1987a; Lenox et al., 1988; Thompson and Fisher, 1990; but see also Eva et al., 1990). In SK-N-SH neuroblastoma cells, inositol lipid hydrolysis proceeds at a constant rate during a period in which $\mathrm{mAChRs}$ are sequestered from the cell surface (Thompson and Fisher, 1990). Because only cell surface mAChRs can activate PLC, the ability of mAChRs to sustain phosphoinositide hydrolysis may reflect their ability to recycle continuously to the cell surface (Thompson and Fisher, 1991).

Adrenergic. Two subtypes $\left(\alpha_{1 \mathrm{~A}}\right.$ and $\left.\alpha_{1 \mathrm{~B}}\right)$ of the $\alpha_{1}$ adrenergic receptor have been defined, on the basis of their susceptibility to alkylation by chloroethylclonidine $\left(\alpha_{1 \mathrm{~B}}>\alpha_{1 \mathrm{~A}}\right)$ and the 10-70-fold greater affinities of two competitive antagonists (WB-4101 or 5-methylurapidil) for the $\alpha_{1 \mathrm{~A}}$ subtype (Minneman, 1988; Hanft and Gross, 1989). Although it has been suggested that the $\alpha_{1 \mathrm{~B}}$ subtype couples to inositol lipid turnover, whereas the $\alpha_{1 \mathrm{~A}}$ receptor is linked to $\mathrm{Ca}^{2+}$ influx 
(Minneman, 1988), such a clear distinction now appears unlikely. In brain slices, norepinephrine-stimulated inositol phosphate formation is inactivated by chloroethylclonidine and is inhibited relatively weakly by WB-4101, thereby implicating the involvement of an $\alpha_{1 \mathrm{~B}}$ subtype (Michel et al., 1990). In contrast, in primary cultures of neurons and glia, alkylation has little effect on norepinephrine-stimulated inositol phosphate release, whereas WB-4101 is a potent inhibitor. Furthermore, unlike the case in brain slices, phosphoinositide turnover in primary cultures is blocked by pertussis toxin (Wilson and Minneman, 1990). In SK-N-MC neuroepithelioma cells, the $\alpha_{1 \mathrm{~A}}$ receptor appears to be the major subtype linked to inositol lipid turnover (Fisher and Landon, 1991). These findings suggest that both $\alpha_{1 \mathrm{~A}}$ and $\alpha_{\mathrm{IB}}$ subtypes have the potential to activate phosphoinositide hydrolysis.

Glutamate. Progress in the pharmacological characterization of the metabotropic glutamate receptor has been aided by the recent introduction of the relatively selective agonist, 1-aminocyclopentyl-1,3-dicarboxylic acid (ACPD) ${ }^{1}$ (Palmer et al., 1989; Desai and Conn, 1990; Manzoni et al., 1990). The ability of this rigid analogue of glutamate to activate effectively the metabotropic, but not the ionotropic, excitatory amino acid receptor has been demonstrated in both brain slices and cultured neurons and is in contrast to the relative nonselectivity of quisqualic and ibotenic acids. The availability of a more potent, but noncompetitive, antagonist, 2-amino-3-phosphonopropionic acid, may also facilitate characterization and functional analysis of this receptor (Schoepp et al., 1990a). In some preparations, a portion of the phosphoinositide turnover induced by quisqualate may be due to activation of ionotropic receptors, perhaps as a result of activation of PLC by elevated $\left[\mathrm{Ca}^{2+}\right]_{\mathrm{i}}$ (Alexander et al., 1990; Baird and Nahorski, 1990b). A G-protein link with the metabotropic glutamate receptor is evidenced by the reported sensitivity of its phosphoinositide response to pretreatment with pertussis toxin, a property which distinguishes this receptor from most other CNS phosphoinositide-linked receptors thus far examined (Nicoletti et al., 1988; Ambrosini and Meldolesi, 1989). Earlier studies demonstrating enhanced coupling in neonatal rat brain suggested a role for metabotropic glutamate receptors in neuronal plasticity. Further support for this concept is provided by reports that signal transduction at this receptor is enhanced following hypoxic-ischemic brain injury (Chen et al., 1988; Seren et al., 1989) and following lesions in the hippocampus, striatum, and amygdala (Nicoletti et al., 1987; Akiyama et al., 1989). In addition, in developing cat visual cortex, the critical period for synaptic modification coincides with a transient rise in the ability of glutamate to stimulate phosphoinositide turnover, a

\footnotetext{
${ }^{1}$ Although previously designated as trans-ACPD, it is in fact cisACPD (see Schoepp et al., 1990b).
}

phenomenon which is absent in kittens raised in the dark (Dudek and Bear, 1989). Further details regarding the properties of the metabotropic glutamate receptor may be found in a recent review by Schoepp et al. $(1990 b)$. Further characterization of this receptor should be facilitated by its recent cloning from rat brain (Houamed et al., 1991; Masu et al., 1991). The nucleotide sequence of the metabotropic glutamate receptor encodes a protein with a molecular mass of 133 $\mathrm{kDa}$ and no apparent homology to other known members of the $\mathrm{G}$ protein-coupled receptor family.

Endothelin. In addition to its potent vasoconstrictive effects on vascular smooth muscle, endothelin (ET) is also synthesized in the CNS where it may exert a neuroregulatory role. The ETs exhibit an unusually high degree of sequence homology with the sarafotoxins (SRTXs), venoms derived from the Israeli snake $A C$ tractapsis eingadensis. High-affinity SRTX/ET binding sites exist within the CNS and exhibit a distinctive regional distribution (Kloog et al., 1988; C. R. Jones et al., 1989). Moreover, the addition of either SRTX or ET elicits an increased phosphoinositide turnover in several brain regions, in cultured $\mathrm{C}_{6}$ glioma cells, and in primary cultures of both neurons and glia. All three forms of ET (ET-1, ET-2, and ET-3) have been shown to activate inositol lipid hydrolysis (but with different potencies). Although the precise role of ET-stimulated phosphoinositide turnover in neural function is not known, a role in mitogenesis has been suggested (MacCumber et al., 1990).

\section{Category II}

Purinergic. There is now a considerable body of evidence to suggest that ATP serves as a neuromodulator in both the CNS and PNS. The addition of ATP to a variety of neural preparations can elicit an increase in phosphoinositide turnover, whereas adenosine and AMP are relatively ineffective. The receptor involved can thus be classified as $P_{2}$ purinergic rather than $P_{1}$ (Burnstock and Kennedy, 1985). However, given the ability of pyrimidines (CTP and UTP) to enhance inositol phosphate release in adrenal (Sasakawa et al., 1989) and other nonneural tissues, the term "nucleotidoceptor" may be most appropriate (Pfeilschifter, 1990). Although $P_{2}$ receptors can be subdivided pharmacologically into $P_{2 y}$ or $P_{2 x}$ subtypes (Burnstock and Kennedy, 1985), it is not yet possible to ascribe phosphoinositide turnover to either of these receptors in neural tissues. In the adrenal medulla, in which the pharmacology of the response has been carefully examined, the characteristics fit neither of the known profiles (Allsup and Boarder, 1990).

Neuropeptides. The list of neuropeptide receptors implicated in phosphoinositide hydrolysis continues to grow. Those for neuropeptide $Y$, gastrin-releasing peptide, oxytocin, and gonadotropin-releasing hormone have been identified recently. Many of these neuropeptide receptors are to be found in primary cultures of glia. Cholewinski et al. (1988) examined the ability 
of 12 neuropeptides to enhance inositol lipid turnover in astrocytes obtained from cerebral cortex, cerebellum, and spinal cord. Each culture displayed a unique pattern of neuropeptide stimulation. Thus, whereas all three tissues responded to bradykinin, eledoisin, and neurokinin $\beta$, the addition of oxytocin and vasopressin elicited a response only in cortical and cerebellar cultures. Only spinal cord cultures responded to substance $\mathrm{P}$ and neurokinin $\alpha$. The regional responsiveness of astrocytes to peptides approaches that displayed by neurons.

\section{Other CNS receptors}

Dopamine. Conflicting reports exist regarding the ability of dopamine to enhance phosphoinositide turnover. No effects of dopamine on either basal or stimulated inositol phosphate release were observed by Kelly et al. (1988) and Rubinstein and Hitzemann (1990), whereas the stimulatory effect reported by Dyck (1990) could be blocked by the $\alpha_{1}$ antagonist, prazosin Wallace and Claró (1990) reported a negative effect on carbachol-stimulated release in membranes following $\mathrm{D}_{1}$-receptor activation. In contrast, Undie and Friedman (1990) have provided compelling evidence for the involvement of $D_{1}$ receptors in rat striatum. In this context, it may be relevant that injection of mRNA from rat striatum into oocytes results in the expression of a $D_{1}$ receptor linked to both $\mathrm{IP}_{3}$ production and $\mathrm{Ca}^{2+}$ efflux (Mahan et al., 1990).

Opioid. Opiates have been reported either to have no effect on, to stimulate, or to inhibit inositol lipid hydrolysis (Bunn et al., 1988; Misawa et al., 1990; Periyasamy and Hoss, 1990).

\section{Modulation of receptor-stimulated phosphoinositide hydrolysis}

Given the complexity of neural tissue, it is not surprising that activation of inositol lipid-linked receptors is itself subject to modulation following agonist occupancy of certain pharmacologically distinct receptors. Both positive and negative modulations (and species dependence) have been reported (Table 4). The underlying molecular mechanisms of such regulation often remain obscure, due perhaps either to the absence of selective antagonist data, to difficulty in excluding the involvement of secondary effects, such as interneuronal communication or depolarization, or to the concurrent rise or fall in intracellular concentrations of other second messengers (e.g., cyclic AMP).

\section{STRATEGIES FOR INTERVENTION OF PHOSPHOINOSITIDE SIGNAL TRANSDUCTION}

Within the series of events that link receptor occupancy to PLC activation, a number of sites might be amenable to pharmacological disruption. From the viewpoint of drug development, the receptor is an obvious target, because it is extracellular and thus accessible. The expression of individual receptor molecules in cells following transfection with appropriate cDNA clones and demonstration of their functional coupling to phosphoinositide turnover may allow for the identification of "tailored subtype-specific" ligands (Lester, 1988), which may be useful in drug development. Intervention at the level of the $\mathrm{G}_{\mathrm{p}}$-PLC interaction is more problematic due to the uncertainty of $G_{p}$ 's iden-

TABLE 4. Modulation of receptor-stimulated phosphoinositide hydrolysis in brain

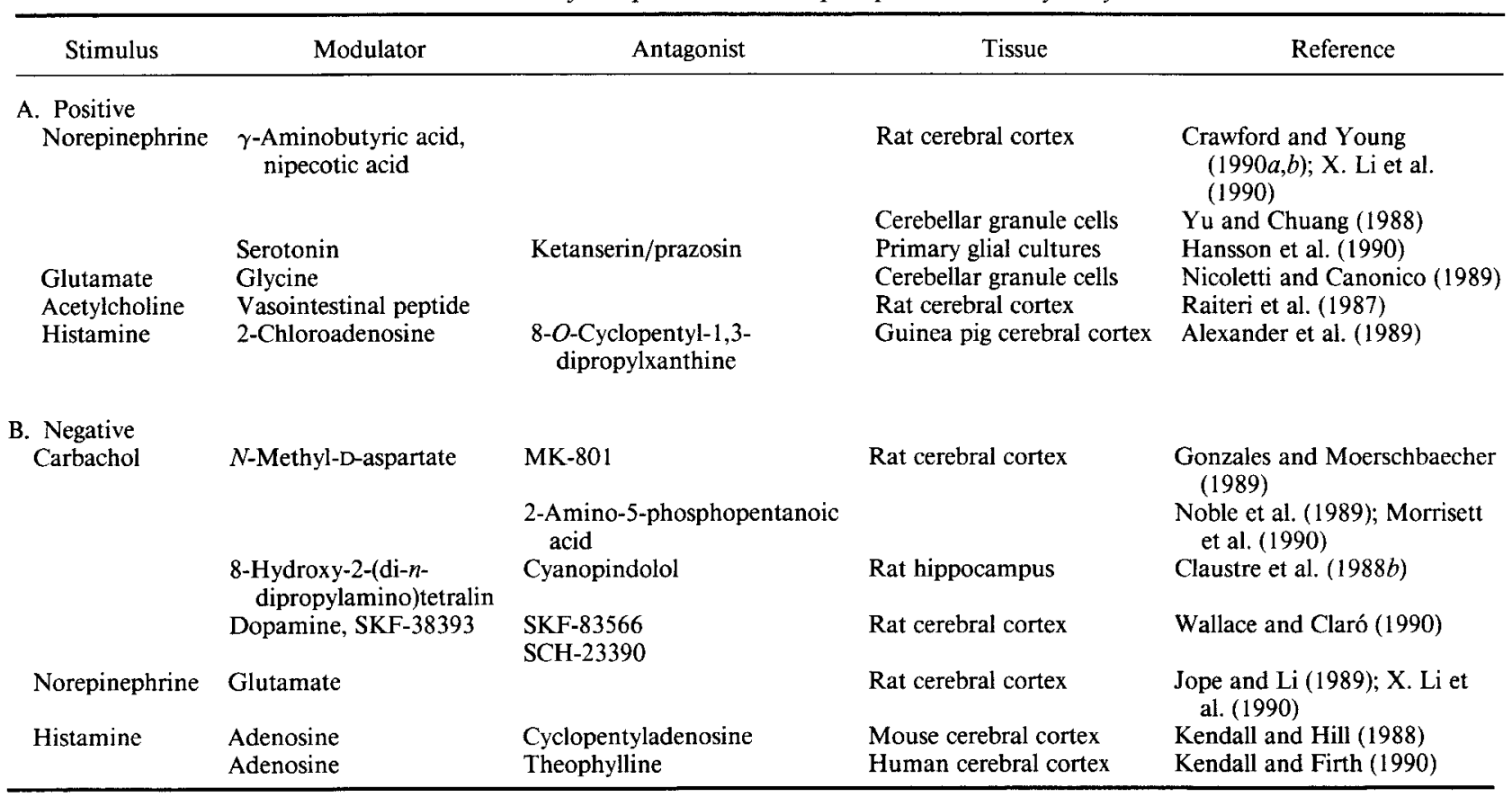


tity, its insensitivity to either cholera or pertussis toxins, and the existence of multiple isozymes of PLC. Nonetheless, assuming $G_{p}$ is a heterotrimer, one potential approach would be the use of synthetic peptides corresponding to known regions of the $\alpha$ subunit of the $G$ protein, the 40 carboxyl-terminal amino acids of which are highly conserved (Hamm et al., 1988). As previously discussed, inhibitors of specific PLC-isozyme activation are not as yet identified. For investigation of the interrelationship between the product of PLC action, i.e., $\mathrm{I}(1,4,5) \mathrm{P}_{3}$, its receptor, and $\mathrm{Ca}^{2+}$ mobilization, the recent development of synthetic $\mathrm{IP}_{3}$ analogues that are resistant to hydrolysis offers promise (Willcocks et al., 1988).

At present, the strategy of limiting the availability of lipid substrates has attracted most attention. Previously, inositol analogues have been shown to be effective inhibitors of brain cytidine diphosphodiacylglycerol (CDP-DAG) inositol transferase, the enzyme responsible for PI synthesis (Benjamins and Agranoff, 1969; see also Agranoff and Fisher, 1991). In addition, Moyer et al. (1988) have demonstrated that two analogues, 5-deoxy-myo-inositol and 5-deoxy-5-fluoromyo-inositol, can permeate intact cells and be incorporated into cellular inositol phospholipid. This "fraudulent" lipid, however, can only be phosphorylated at the 4-position of the inositol ring, and hence $\mathrm{PIP}_{2}$ cannot be synthesized. Interference with inositol lipid synthesis is considered to be an explanation for the antimanic effect of $\mathrm{Li}^{+}$in humans (Berridge et al., 1982). Largely as a result of studies by Sherman and colleagues, it is now established that "therapeutically" relevant concentrations of $\mathrm{Li}^{+}$in the rat result in the accumulation of inositol phosphates both in vivo and in vitro, the result of selective inhibition of inositol monophosphatase (Allison et al., 1976; Hallcher and Sherman, 1980). The net effect is to reduce the availability of inositol, which could theoretically reduce PI synthesis, given the limited permeability of the bloodbrain barrier to inositol. Because the mode of inhibition by $\mathrm{Li}^{+}$is uncompetitive (i.e., $\mathrm{Li}^{+}$binds to the $\mathrm{E} \cdot \mathrm{S}$ complex), lipid resynthesis is anticipated to be most compromised in hyperactive neurons which should produce correspondingly larger amounts of $\mathrm{IP}_{1}$. Whereas experimental evidence has been obtained in favor of a link between $\mathrm{Li}^{+}$and phosphoinositide turnover (Casebolt and Jope, 1987; Kendall and Nahorski, 1987; Godfrey et al., 1989), questions still remain. For example, although the addition of $\mathrm{Li}^{+}$to tissue incubations results in the accumulation of CDP-DAG (due to inositol depletion), a reduction of agonist-stimulated $\mathrm{PIP}_{2}$ breakdown invariably is not found, suggesting the existence of a pool of lipid that is spared the effects of $\mathrm{Li}^{+}$(Drummond and Raeburn, 1984; Downes and Stone, 1986). Furthermore, chronic administration (27-39 days) of $\mathrm{Li}^{+}$to rats failed to alter significantly the concentration of brain PI, PIP, or PIP (Honchar $_{2}$ et al., 1989), nor did this treatment influence the extent of $I(1) P_{1}$ accumulation observed in the presence of muscarinic agonists (Honchar et al., 1990). A deficit in the phosphoinositide pathway has also been proposed in the PNS in diabetic neuropathy (Greene and Lattimer, 1985).

\section{CONCLUDING REMARKS}

In the 4 years that have elapsed since we last reviewed phosphoinositides in the nervous system, there have been more publications than in the entire preexisting literature. It is daunting from the standpoint of writing a minireview that the rate of publication continues to accelerate. Among novel findings since 1987 is the presence in many tissues, including brain, of PI-linked proteins. The recent findings of intracellular $\mathrm{PIP}_{2}$ and $\mathrm{IP}_{3}$ binding proteins and of 3-phosphoinositides certainly will have implications eventually for brain function. It is likely that there will be yet other revelations in the years to come.

Acknowledgment: The authors wish to thank Ms. Jo Ann Kelsch for preparation of the manuscript. This work was supported by NIH grant NS 23831 (S.K.F.) and by NIMH grant MH 24652 (S.K.F., A.M.H., and B.W.A.).

\section{REFERENCES}

Ackermann K. E., Gish B. G., Honchar M. P., and Sherman W. R. (1987) Evidence that inositol 1-phosphate in brain of lithiumtreated rats results mainly from phosphatidylinositol metabolism. Biochem. J. 242, 517-524

Agranoff B. W. (1978) Cyclitol confusion. Trends Biochem. Sci. 3, N283-N285.

Agranoff B. W. and Fisher S. K. (1991) Phosphoinositides and their stimulated breakdown, in Inositol Phosphates and Related Compounds: Synthesis and Therapeutic Potential (Reitz A. B., ed). Washington, D.C. American Chemical Society, pp. 20-32.

Akil M. and Fisher S. K. (1989) Muscarinic receptor-stimulated phosphoinositide turnover in human SK-N-SH neuroblastoma cells: differential inhibition by agents that elevate cyclic AMP. J. Neurochem. 53, 1479-1486.

Akins P. T., Surmeier D. J., and Kitai S. T. (1990) $M_{1}$ muscarinic acetylcholine receptor in cultured rat neostriatum regulates phosphoinositide hydrolysis. $J$. Neurochem. 54, 266-273.

Akiyama K., Yamada N., and Otsuki S. (1989) Lasting increase in excitatory amino acid receptor-mediated polyphosphoinositide hydrolysis in the amygdala/pyriform cortex of amygdala-kindled rats. Brain Res. 485, 95-101.

Alexander S. P. H., Kendall D. A., and Hill S. J. (1989) Differences in the adenosine receptors modulating inositol phosphates and cyclic AMP accumulation in mammalian cerebral cortex. $\mathrm{Br}$. J. Pharmacol. 98, 1241-1248.

Alexander S. P. H., Hill S. J., and Kendall D. A. (1990) Excitatory amino acid-induced formation of inositol phosphates in guineapig cerebral cortical slices: involvement of ionotropic or metabotropic receptors? J. Neurochem. 55, 1439-1441.

Allison J. H., Blisner M. E., Holland W. H., Hipps P. P., and Sherman W. R. (1976) Increased brain myo-inositol 1-phosphate in lithium-treated rats. Biochem. Biophys. Res. Commun. 71, 664670 .

Allsup D. J. and Boarder M. R. (1990) Comparison of $P_{2}$ purinergic receptors of aortic endothelial cells with those of adrenal medulla: evidence for heterogeneity of receptor subtype and of inositol phosphate response. Mol. Pharmacol. 38, 84-91.

Ambrosini A. and Meldolesi J. (1989) Muscarinic and quisqualate receptor-induced phosphoinositide hydrolysis in primary cultures 
of striatal and hippocampal neurons. Evidence for differential mechanisms of activation. $J$. Neurochem. 53, 825-833.

Ananth U. S., Leli U., and Hauser G. (1987) Stimulation of phosphoinositide hydrolysis by serotonin in $\mathrm{C}_{6}$ glioma cells. $\mathrm{J}$. Neurochem. 48, 253-261.

Arbonés L., Picatoste F., and García A. (1988) Histamine $\mathrm{H}_{1}$-receptors mediate phosphoinositide hydrolysis in astrocyte-enriched primary cultures. Brain Res. 450, 144-152.

Ashkenazi A., Ramachandran J., and Capon D. J. (1989) Acetylcholine analogue stimulates DNA synthesis in brain-derived cells via specific muscarinic receptor subtypes. Nature 340, 146-150.

Baird J. G. and Nahorski S. R. (1990a) Differences between muscarinic-receptor- and $\mathrm{Ca}^{2+}$-induced inositol polyphosphate isomer accumulation in rat cerebral-cortex slices. Biochem. J. 267, 835-838.

Baird J. G. and Nahorski S. R. (1990b) Quisqualate stimulates phosphoinositide metabolism by interaction with more than one receptor mechanism. Br. J. Pharmacol. (suppl.) $100,315$.

Barrett R. W., Steffey M. E., and Wolfram C. A. W. (1989) Type-A cholecystokinin receptors in CHP2 12 neuroblastoma cells: evidence for association with $\mathrm{G}$ protein and activation of phosphoinositide hydrolysis. Mol. Pharmacol. 35, 394-400.

Batty I. H. and Nahorski S. R. (1989) Rapid accumulation and sustained turnover of inositol phosphates in cerebral-cortex slices after muscarinic-receptor stimulation. Biochem. J. 260, 237241.

Baumgold J. and White T. (1989) Pharmacological differences between muscarinic receptors coupled to phosphoinositide turnover and those coupled to adenylate cyclase inhibition. Biochem. Pharmacol. 38, 1605-1616.

Benjamins J. A. and Agranoff B. W. (1969) Distribution and properties of CDP-diglyceride: inositol transferase from brain. J. Neurochem. 16, 513-527.

Berridge M. J. and Irvine R. F. (1989) Inositol phosphates and cell signalling. Nature 341, 197-205.

Berridge M. J., Downes C. P., and Hanley M. R. (1982) Lithium amplifies agonist-dependent phosphatidylinositol responses in brain and salivary glands. Biochem. J. 206, 587-595.

Blackstone C. D., Supattapone S., and Snyder S. H. (1989) Inositolphospholipid-linked glutamate receptors mediate cerebellar parallel-fiber-Purkinje-cell synaptic transmission. Proc. Natl. Acad. Sci. USA 86, 4316-4320.

Bleasdale J. E., Thakur N. R., Gremban R. S., Bundy G. L., Fitzpatrick F. A., Smith R. J., and Bunting S. (1990) Selective inhibition of receptor-coupled phospholipase C-dependent processes in human platelets and polymorphonuclear neutrophils. J. Pharmacol. Exp. Ther. 255, 756-768.

Bonner T. I., Buckley N. J., Young A. C., and Brann M. R. (1987) Identification of a family of muscarinic acetylcholine receptor genes. Science 237, 527-532.

Bonner T. I., Young A. C., Brann M. R., and Buckley N. J. (1988) Cloning and expression of the human and rat $\mathrm{m} 5$ muscarinic acetylcholine receptor genes. Neuron 1, 403-410.

Boyer J. L., Hepler J. R., and Harden T. K. (1989) Hormone and growth factor receptor-mediated regulation of phospholipase $\mathrm{C}$ activity. Trends Pharmacol. Sci. 10, 360-364.

Brooks P. A. and Spyer K. M. (1989) Investigation of inositol hexakisphosphate actions in rat nucleus tractus solitarius in vitro. Neurosci. Lett. 105, 120-124.

Bunn S. J., Marley P. D., and Livett B. G. (1988) Effects of opioid compounds on basal and muscarinic induced accumulation of inositol phosphates in cultured bovine chromaffin cells. Biochem. Pharmacol. 37, 395-399.

Burgess G. M., Mullaney I., McNeill M., Dunn P. M., and Rang H. P. (1989) Second messengers involved in the mechanism of action of bradykinin in sensory neurons in culture. J. Neurosci. 9, 3314-3325.

Burnstock G. and Kennedy C. (1985) Is there a basis for distinguishing two types of $\mathrm{P}_{2}$-purinoceptor? Gen. Pharmacol. 16, 433-440.

Campbell M. D., Subramaniam S., Kotlikoff M. I., Williamson J. R., and Fluharty S. J. (1990) Cyclic AMP inhibits inositol polyphosphate production and calcium mobilization in neuro- blastoma $\times$ glioma NG108-15 cells. Mol. Pharmacol. 38, 282288.

Carpenter C. L. and Cantley L. C. (1990) Phosphoinositide kinases. Biochemistry 29, 11147-11156.

Carrithers M. D., Raman V. K., Masuda S., and Weyhenmeyer J. A. (1990) Effect of angiotensin II and III on inositol polyphosphate production in differentiated NG108-15 hybrid cells. Biochem. Biophys. Res. Commun. 167, 1200-1205.

Carter H. R., Wallace M. A., and Fain J. N. (1990a) Activation of phospholipase $\mathrm{C}$ in rabbit brain membranes by carbachol in the presence of GTPrS; effects of biological detergents. Biochim. Biophys. Acta 1054, 129-135.

Carter H. R., Wallace M. A., and Fain J. N. (1990b) Purification and characterization of PLC- $\beta_{\mathrm{m}}$, a muscarinic cholinergic regulated phospholipase $\mathrm{C}$ from rabbit brain membrane. Biochim. Biophys. Acta 1054, 119-128.

Casebolt T. and Jope R. S. (1987) Chronic lithium treatment reduces norepinephrine-stimulated inositol phospholipid hydrolysis in rat cortex. Eur. J. Pharmacol. 140, 245-246.

Challis R. A. J. and Nahorski S. R. (1990) Neurotransmitter and depolarization-stimulated accumulation of inositol 1,3,4,5-tetrakisphosphate mass in rat cerebral cortex slices. $J$. Neurochem. 54, 2138-2141.

Challis R. A. J., Batty I. H., and Nahorski S. R. (1988) Mass measurements of inositol $(1,4,5)$ trisphosphate in rat cerebral cortex slices using a radioreceptor assay: effects of neurotransmitters and depolarization. Biochem. Biophys. Res. Cormmun. 157, 684691.

Challis R. A. J., Chilvers E. R., Willcocks A. L., and Nahorski S. R. (1990) Heterogeneity of $\left[{ }^{3} \mathrm{H}\right]$ inositol 1,4,5-trisphosphate binding sites in adrenal-cortical membranes. Biochem. J. 265, 421-427.

Chan B. L., Chao M. V., and Saltiel A. R. (1989) Nerve growth factor stimulates the hydrolysis of glycosylphosphatidylinositol in PC12 cells: a mechanism of protein kinase $\mathrm{C}$ regulation. Proc. Natl. Acad. Sci. USA 86, 1756-1760.

Chen C.-K., Silverstein F. S., Fisher S. K., Statman D., and Johnson M. V. (1988) Perinatal hypoxic-ischemic brain injury enhances quisqualic acid-stimulated phosphoinositide turnover. $J$. Nettrochem. 51, 353-359.

Chiang C.-F. and Hauser G. (1989) Effects of bradykinin, GTP $\gamma$ S, R59022 and $N$-ethylmaleimide on inositol phosphate production in NG108-15 cells. Biochem. Biophys. Res. Commun. 165, 175181.

Chiu A. S., Li P. P., and Warsh J. J. (1988) G-protein involvement in central-nervous-system muscarinic-receptor-coupled polyphosphoinositide hydrolysis. Biochem. J. 256, 995-999.

Choi K. Y., Kim H. K., Lee S. Y., Moon K. H., Sim S. S., Kim J. W., Chung H. K., and Rhee S. G. (1990) Molecular cloning and expression of a complementary DNA for inositol 1,4,5-trisphosphate 3-kinase. Science 248, 64-66.

Choi W. C., Gerfen C. R., Suh P. G., and Rhee S. G. (1989) Immunohistochemical localization of a brain isozyme of phospholipase C (PLC III) in astroglia in rat brain. Brain Res. 499, 193197.

Cholewinski A. J., Hanley M. R., and Wilkin G. P. (1988) A phosphoinositide-linked peptide response in astrocytes: evidence for regional heterogeneity. Neurochem. Res. 13, 389-394.

Chuang D.-M. and Dillon-Carter O. (1988) Characterization of bradykinin-induced phosphoinositide turnover in neurohybrid NCB-20 cells. J. Neurochem. 51, 505-513.

Cioffi C. L. and Fisher S. K. (1990) Reduction of muscarinic receptor density and of guanine-nucleotide stimulated phosphoinositide hydrolysis in human SH-SY-5Y neuroblastoma cells following long-term treatment with 12-O-tetradecanoylphorbol-13-acetate or mezerein. $J$. Neurochem. 54, 1725-1734.

Claró E., Garcia A., and Picatoste F. (1989) Carbachol and histamine stimulation of guanine-nucleotide-dependent phosphoinositide hydrolysis in rat brain cortical membranes. Biochem. J. 261, 29-35.

Claustre Y., Rouquier L., and Scatton B. (1988a) Pharmacological characterization of serotonin-stimulated phosphoinositide turn- 
over in brain regions of the immature rat. J. Pharmacol. Exp. Ther. 244, 1051-1056.

Claustre Y., Bénavidès J., and Scatton B. (1988b) 5-HT IA $_{\text {receptor }}$ agonists inhibit carbachol-induced stimulation of phosphoinositide turnover in the rat hippocampus. Eur. J. Pharmacol. 149, 149-153.

Cochet C. and Chambaz E. M. (1986) Catalytic properties of a purified phosphatidylinositol-4-phosphate kinase from rat brain. Biochem. J. 273, 25-31.

Crawford M. L. A. and Young J. M. (1990a) $\mathrm{Ca}^{2+}$-dependence provides evidence for differing mechanisms of GABA-induced inositol phosphate formation and GABA potentiation of inositol phosphate formation induced by noradrenaline in rat cerebral cortex. Mol. Brain Res. 8, 181-183.

Crawford M. L. A. and Young J. M. (1990b) Potentiation by $\gamma$ aminobutyric acid of $\alpha_{1}$-agonist-induced accumulation of inositol phosphates in slices of rat cerebral cortex. J. Neurochem. 54, 2100-2109.

Crawford M. L. A., Hiley C. R., and Young J. M. (1990) Characteristics of endothelin- 1 and endothelin-3 stimulation of phosphoinositide breakdown differ between regions of guinea-pig and rat brain. Naunyn-Schmiedebergs Arch. Pharmacol. 341, 268271

Crooke S. T. and Bennett C. F. (1989) Mammalian phosphoinositidespecific phospholipase $C$ isoenzymes. Cell Calcium 10, 309323.

Cubitt A. B., Geras-Raaka E., and Gershengorn M. C. (1990) Thyrotropin-releasing hormone receptor occupancy determines the fraction of the responsive pool of inositol lipids hydrolysed in rat pituitary tumour cells. Biochem. J. 271, 331-336.

Danoff S. K., Supattapone S., and Snyder S. H. (1988) Characterization of a membrane protein from brain mediating the inhibition of inositol 1,4,5-trisphosphate receptor binding by calcium Biochem. J. 254, 701-705.

Danoff S. K., Ferris C. D., Donath C., Fischer G. A., Munemitsu S., Ullrich A., Snyder S. H., and Ross C. A. (1991) Inositol 1,4,5trisphosphate receptors: distinct neuronal and nonneuronal forms derived by alternative splicing differ in phosphorylation. Proc. Natl. Acad. Sci. USA 88, 2951-2955.

Davidson J. S., Wakefield I. K., Sohnius U., van der Merwe P. A., and Millar R. P. (1990) A novel extracellular nucleotide receptor coupled to phosphoinositidase-C in pituitary cells. Endocrinology 126, 80-87.

Day N. S., Berti-Mattera L. N., and Eichberg J. (1991) Muscarinic cholinergic receptor-mediated phosphoinositide metabolism in peripheral nerve. J. Neurochem. 56, 1905-1913.

Desai M. and Conn P. J. (1990) Selective activation of phosphoinositide hydrolysis by a rigid analogue of glutamate. Neurosci. Lett. $109,157-162$.

Desrues L., Tonon M. C., and Vaudry H. (1990) Thyrotropin-releasing hormone stimulates polyphosphoinositide metabolism in the frog neurointermediate lobe. J. Mol. Endocrinol. 5, 129 136.

Diehl R. E., Whiting P., Potter J., Gee N., Ragan I., Linemeyer D., Schoepfer R., Bennett C., and Dixon R. A. F. (1990) Cloning and expression of bovine brain inositol monophosphatase. $J$. Biol. Chem. 265, 5946-5949.

Donié F., Hülser E., and Reiser G. (1990) High-affinity inositol 1,3,4,5-tetrakisphosphate receptor from cerebellum: solubilization, partial purification and characterization. FEBS Lett. 268, 194-198.

Downes C. P. and MacPhee C. H. (1990) myo-Inositol metabolites as cellular signals. Eur. J. Biochem. 193, 1-18.

Downes C. P. and Stone M. A. (1986) Lithium-induced reduction in intracellular inositol supply in cholinergically stimulated parotid gland. Biochem. J. 234, 199-204.

Drummond A. H. and Raeburn C. A. (1984) The interaction of lithium with thyrotropin releasing hormone-stimulated lipid metabolism in $\mathrm{GH}_{3}$ pituitary tumor cells. Biochem. J. 224, 129136.

Dudek S. M. and Bear M. F. (1989) A biochemical correlate of the critical period for synaptic modification in the visual cortex. Science 246, 673-675.

Dudek S. M., Bowen W. D., and Bear M. F. (1989) Postnatal changes in glutamate stimulated phosphoinositide turnover in rat neocortical synaptoneurosomes. Dev. Brain Res. 47, 123-128.

Dyck L. E. (1990) Effects of dopamine on phosphoinositide hydrolysis in slices of rat striatum and cortex. Neurochem. Int. 17, 77-82.

Eberhard D. A. and Holz R. W. (1988) Intracellular $\mathrm{Ca}^{2+}$ activates phospholipase C. Trends Neurosci. 11, 517-520.

Eberhard D. A., Cooper C. L., Low M. G., and Holz R. W. (1990) Evidence that the inositol phospholipids are necessary for exocytosis. Biochem. J. 268, 15-25.

Ehrlich Y. H., Snider R. M., Kornecik E., Garfield M. G., and Lenox R. H. (1988) Modulation of neuronal signal transduction systems by extracellular ATP. J. Neurochem. 50, 295-301.

Eisenberg F. Jr. (1967) D-Myoinositol 1 -phosphate as product of cyclization of glucose 6-phosphate and substrate for a specific phosphatase in rat testis. J. Biol. Chem. 242, 1375-1382.

Ellis J., Huyler J. H., Kemp D. E., and Weiss S. (1990) Muscarinic receptors and second-messenger responses of neurons in primary culture. Brain Res. 511, 234-240.

Emori Y., Homma Y., Sorimachi H., Kawasaki H., Nakanishi O., Suzuki K., and Takenawa T. (1989) A second type of rat phosphoinositide-specific phospholipase $\mathrm{C}$ containing a $s r c$-related sequence not essential for phosphoinositide-hydrolyzing activity. J. Biol. Chem. 264, 21885-21890.

Endemann G., Dunn S. N., Cantley L. C. (1987) Bovine brain contains two types of phosphatidylinositol kinase. Biochemistry $\mathbf{2 6}$ $6845-6852$

Endemann G. C., Graziani A., and Cantley L. C. (1991) A monoclonal antibody distinguishes two types of phosphatidylinositol 4-kinase. Biochem. J. 273, 63-66.

Erneux C., Delvaux A., Moreau C., and Dumont J. E. (1986) Characterization of D-myo-inositol 1,4,5-trisphosphate phosphatase in rat brain. Biochem. Biophys. Res. Commun. 134, 351-358.

Eva C., Gamalero S. R., Genazzani E., and Costa E. (1990) Molecular mechanisms of homologous desensitization and internalization of muscarinic receptors in primary cultures of neonatal corticostriatal neurons. J. Pharmacol. Exp. Ther. 253, 257-265.

Fain J. N., Wallace M. A., and Wojcikiewicz R. J. H. (1988) Evidence for involvement of guanine nucleotide-binding regulatory proteins in the activation of phospholipases by hormones. $F A S E B$ J. 2, 2569-2574.

Ferguson M. A. J. and Williams A. F. (1988) Cell-surface anchoring of proteins via glycosylphosphatidylinositol structures. Annu. Rev. Biochem. 57, 285-320.

Ferris C. D., Huganir R. L.. Supattapone S., and Snyder S. H. (1989) Purified inositol 1,4,5-trisphosphate receptor mediates calcium flux in reconstituted lipid vesicles. Nature 342, 87-89.

Ferris C. D., Huganir R. L., and Snyder S. H. (1990) Calcium flux mediated by purified inositol 1,4,5-trisphosphate receptor in reconstituted lipid vesicles is allosterically regulated by adenine nucleotides. Proc. Natl. Acad. Sci. USA 87, 2147-2151.

Fisher S. K. and Agranoff B. W. (1987) Receptor activation and inositol lipid hydrolysis in neural tissues. $J$. Neurochem. 48, 999 1016.

Fisher S. K. and Heacock A. M. (1988) A putative $M_{3}$ muscarinic cholinergic receptor of high molecular weight couples to phosphoinositide hydrolysis in human SK-N-SH neuroblastoma cells. J. Neurochem. 50, 984-987.

Fisher S. K. and L andon R. E. (1991) Identification of multiple phosphoinositide-linked receptors on human SK-N-MC neuroepithelioma cells. $J$. Neurochem. 57, 1599-1608.

Fisher S. K., Domask L. M., and Roland R. M. (1989) Muscarinic receptor regulation of cytoplasmic $\mathrm{Ca}^{2+}$ concentrations in human SK-N-SH neuroblastoma cells: $\mathrm{Ca}^{2+}$ requirements for phospholipase C activation. Mol. Pharmacol. 35, 195-204.

Fisher S. K., Heacock A. M., Seguin E. B., and Agranoff B. W. (1990) Polyphosphoinositides are the major source of inositol phosphates in carbamoylcholine-stimulated SK-N-SH neuroblastoma cells. Mol. Pharmacol. 38, 54-63. 
Forray C. and El-Fakahany E. E. (1990) On the involvement of multiple muscarinic receptor subtypes in the activation of phosphoinositide metabolism in rat cerebral cortex. Mol. Pharmacol. 37 , 893-902.

Fouchier F., Baltz T., and Rougon G. (1990) Identification of glycosylphosphatidylinositol-specific phospholipases $\mathrm{C}$ in mouse brain membranes. Biochem. J. 269, 321-327.

Furuichi T., Yoshikawa S., Miyawaki A., Wada K., Maeda N., and Mikoshiba K. (1989) Primary structure and functional expression of the inositol 1,4,5-trisphosphate-binding protein $\mathbf{P}_{400}$. Nature $342,32-38$.

Gammon C. M., Allen A. C., and Morell P. (1989) Bradykinin stimulates phosphoinositide hydrolysis and mobilization of arachidonic acid in dorsal root ganglion neurons. $J$. Neurochem. $\mathbf{5 3}$, 95-101.

Gee N. S., Reid G. G., Jackson R. G., Barnaby R. J., and Ragan C. I. (1988a) Purification and properties of inositol-1,4-bisphosphatase from bovine brain. Biochem. J. 253, 777-782.

Gee N. S., Ragan C. I., Watling K. J., Aspley S., Jackson R. G., Reid G. G., Gani D., and Shute J. K. (1988b) The purification and properties of myo-inositol monophosphatase from bovine brain. Biochem. J. 249, 883-889.

Gerfen C. R., Choi W. C., Suh P. G., and Rhee S. G. (1988) Phospholipase C I and II brain isozymes: immunohistochemical localization in neuronal systems in rat brain. Proc. Natl. Acad. Sci. USA 85, 3208-3212.

Godfrey P. P. and Watson S. P. (1988) Fluoride inhibits agonistinduced formation of inositol phosphates in rat cortex. Biochem. Biophys. Res. Commun. 155, 664-669.

Godfrey P. P., McClue S. J., Young M. M., and Heal D. J. (1988) 5-Hydroxytryptamine-stimulated inositol phospholipid hydrolysis in the mouse cortex has pharmacological characteristics compatible with mediation via $5-\mathrm{HT}_{2}$ receptors but this response does not reflect altered 5- $\mathrm{HT}_{2}$ function after 5,7-dihydroxytryptamine lesioning or repeated antidepressant treatments. $\mathrm{J}$. Neurochem. 50, 730-738.

Godfrey P. P., McClue S. J., White A. M., Wood A. J., and GrahameSmith D. G. (1989) Subacute and chronic in vivo lithium treatment inhibits agonist- and sodium fluoride-stimulated inositol phosphate production in rat cortex. $J$. Neurochem. 52, 498-506.

Goldschmidt-Clermont P. J., Machesky L. M., Baldassare J. J., and Pollard T. D. (1990) The actin-binding protein profilin binds to $\mathrm{PIP}_{2}$ and inhibits its hydrolysis by phospholipase C. Science 247, $1575-1578$.

Gonzales R. A. and Crews F. T. (1985) Guanine nucleotides stimulate production of inositol trisphosphate in rat cortical membranes. Biochem. J. 232, 799-804.

Gonzales R. A. and Crews F. T. (1988) Differential regulation of phosphoinositide phosphodiesterase activity in brain membranes by guanine nucleotides and calcium. $J$. Neurochem. 50, 15221528.

Gonzales R. A. and Moerschbaecher J. M. (1989) A phencyclidine recognition site is associated with $N$-methyl-D-aspartate inhibition of carbachol-stimulated phosphoinositide hydrolysis in rat cortical slices. Mol. Pharmacol. 35, 787-794.

Grandison L. (1990) Platelet activating factor induces inositol phosphate accumulation in cultures of rat and bovine anterior pituitary cells. Endocrinology 127, 1786-1791.

Greene D. A. and Lattimer S. A. (1985) Altered nerve myo-inositol metabolism in experimental diabetes and its relationship to nerve function, in Inositol and Phosphoinositides: Metabolism and Biological Regulation (Bleasdale J. E., Eichberg J., Hauser G., eds), pp. 563-582. Humana Press, Clifton, New Jersey,

Guiramand J., Sassetti I., and Recasens M. (1989) Developmental changes in the chemosensitivity of rat brain synaptoneurosomes to excitatory amino acids, estimated by inositol phosphate formation. Int. J. Dev. Neurosci. 7, 257-266.

Guiramand J., Mayat E., Bartolami S., Lenoir M., Rumigny J.-F., Pujol R., and Récasens M. (1990) A M $\mathbf{M}_{3}$ muscarinic receptor coupled to inositol phosphate formation in the rat cochlea? Biochem. Pharmacol. 39, 1913-1919.
Gusovsky F., Yasumoto T., and Daly J. W. (1989) Maitotoxin, a potent, general activator of phosphoinositide breakdown. FEBS Lett. 243, 307-312.

Hallcher L. M. and Sherman W. R. (1980) The effects of lithium ion and other agents on the activity of myo-inositol-1-phosphatase from bovine brain. J. Biol. Chem. 255, 10896-10901.

Hamm H. E., Deretic D., Arendt A., Hargrave P. A., Koenig B., and Hofmann K. P. (1988) Site of $G$ protein binding to rhodopsin mapped with synthetic peptides from the $\alpha$ subunit. Science 241, 832-835.

Hanft G. and Gross G. (1989) Subclassification of $\alpha_{1}$-adrenoceptor recognition sites by urapidil derivatives and other selective antagonists. Br. J. Pharmacol. 97, 691-700.

Hansen C. A., Johanson R. A., Williamson M. T., and Williamson J. R. (1987) Purification and characterization of two types of soluble inositol phosphate 5-phosphomonoesterases from rat brain. J. Biol. Chem. 262, 17319-17326.

Hansson E., Simonsson P., and Alling C. (1990) Interactions between cyclic AMP and inositol phosphate transduction systems in astrocytes in primary culture. Neuropharmacology 29, 591-598.

Harootunian A. T., Kao J. P. Y., Paranjape S., and Tsien R. Y. (1991) Generation of calcium oscillations in fibroblasts by positive feedback between calcium and $\mathrm{IP}_{3}$. Science $251,75-78$.

Harwood J. L. and Hawthorne J. N. (1969) The properties and subcellular distribution of phosphatidylinositol kinase in mammalian tissues. Biochim. Biophys. Acta 171, 75-88.

Hawkins P. T., Reynolds D. J. M., Poyner D. R., and Hanley M. R. (1990) Identification of a novel inositol phosphate recognition site: specific $\left[{ }^{3} \mathrm{H}\right]$ inositol hexakisphosphate binding to brain regions and cerebellar membranes. Biochem. Biophys. Res. Commun. 167, 819-827.

Heacock A. M., Seguin E. B., and Agranoff B. W. (1990) Developmental and regional studies of the metabolism of inositol 1,4,5trisphosphate in rat brain. $J$. Neurochem. 54, 1405-1411.

Hide I., Kato T., and Yamawaki S. (1989) In vivo determination of 5-hydroxytryptamine receptor-stimulated phosphoinositide turnover in rat brain. $J$. Neurochem. 53, 556-560.

Höer D., Kwiatkowski A., Seib C., Rosenthal W., Schultz G., and Oberdisse E. (1988) Degradation of inositol 1,3,4,5-tetrakisphosphate by porcine brain cytosol yields inositol 1,3,4-trisphosphate and inositol 1,4,5-trisphosphate. Biochem. Biophys. Res. Commun. 154, 668-675.

Höer A., Höer D., and Oberdisse E. (1990) Properties of a soluble inositol 1,3,4,5-tetrakisphosphate 3-phosphatase from porcine brain. Biochem. J. 270, 715-719.

Hollingsworth E. B. (1989) Gastrin-releasing peptide receptor in rat brain membranes: specific binding and stimulation of phosphoinositide breakdown. Mol. Pharmacol. 35, 689-694.

Homma Y., Imaki J., Nakanishi O., and Takenawa T. (1988) Isolation and characterization of two different forms of inositol phospholipid-specific phospholipase $\mathrm{C}$ from rat brain. J. Biol. Chem. 263, 6592-6598.

Honchar M. P., Ackermann K. E., and Sherman W. R. (1989) Chronically administered lithium alters neither myo-inositol monophosphatase activity nor phosphoinositide levels in rat brain. J. Neurochem. 53, 590-594.

Honchar M. P., Vogler G. P., Gish B. G., and Sherman W. R. (1990) Evidence that phosphoinositide metabolism in rat cerebral cortex stimulated by pilocarpine, physostigmine, and pargyline in vivo is not changed by chronic lithium treatment. J. Neurochem. 55, 1521-1525.

Horwitz J. (1989) Muscarinic receptor stimulation increases inositolphospholipid metabolism and inhibits cyclic AMP accumulation in PC12 cells. J. Neurochem. 53, 197-204.

Houamed K. M., Kuijper J. L., Gilbert T. L., Haldeman B. A., O'Hara P. J., Mulvihill E. R., Almers W., and Hagen F. S. (1991)Cloning, expression, and gene structure of a $\mathrm{G}$ protein-coupled glutamate receptor from rat brain. Science 252, 1318-1321.

Howell S., Barnaby R. J., Rowe T., Ragan C. I., and Gee N. S. (1989) Evidence for at least four different inositol bisphosphatases in bovine brain. Eur. J. Biochem. 183, 169-172. 
Hynie S., Wroblewski J. T., and Costa E. (1989) Profile of phosphatidylinositol metabolism stimulated by carbachol and glutamate in primary cultures of rat cerebellar neurons. Neuropharmacology 28, 1309-1315.

Imaizumi T., Osugi T., Misaki N., Uchida S., and Yoshida H. (1989) Heterologous desensitization of bradykinin-induced phosphatidylinositol response and $\mathrm{Ca}^{2+}$ mobilization by neurotensin in NG108-15 cells. Eur. J. Pharmacol. 161, 203-208.

Inhorn R. C. and Majerus P. W. (1987) Inositol polyphosphate 1phosphatase from calf brain. J. Biol. Chem. 262, 15946-15952.

Inhorn R. C. and Majerus P. W. (1988) Properties of inositol polyphosphate 1-phosphatase. J. Biol. Chem. 263, 14559-14565.

Ivins K. J. and Molinoff P. B. (1990) Serotonin-2 receptors coupled to phosphoinositide hydrolysis in a clonal cell line. Mol. Pharmacol. 37, 622-630.

Ivorra I., Gigg R., Irvine R. F., and Parker I. (1991) Inositol 1,3,4,6tetrakisphosphate mobilizes calcium in Xenopus oocytes with high potency. Biochem. J. 273, 317-321.

Johanson R. A., Hansen C. A., and Williamson J. R. (1988) Purification of D-myo-inositol 1,4,5-trisphosphate 3-kinase from rat brain. J. Biol. Chem. 263, 7465-7471.

Jones C. R., Hiley C. R., Pelton J. T., and Mohr M. (1989) Autoradiographic visualization of the binding sites for $\left[{ }^{125} I\right]$ endothelin in rat and human brain. Neurosci. Lett. 97, 276-279.

Jones T. H., Brown B. L., and Dobson P. R. M. (1989) Bradykinin stimulates phosphoinositide metabolism and prolactin secretion in rat anterior pituitary cells. J. Mol. Endocrinol. 2, 47-53.

Jope R. S. (1988) Modulation of phosphoinositide hydrolysis by NaF and aluminum in rat cortical slices. $J$. Neurochem. 51, 17311736.

Jope R. S. and Li X. (1989) Inhibition of inositol phospholipid synthesis and norepinephrine-stimulated hydrolysis in rat brain slices by excitatory amino acids. Biochem. Pharmacol. 38, 589-596.

Joseph S. K. and Williamson J. R. (1989) Inositol polyphosphates and intracellular calcium release. Arch. Biochem. Biophys. 273, 1-15.

Kanoh H., Yamada K., and Sakane F. (1990) Diacylglycerol kinase: a key modulator of signal transduction? Trends Biochem. Sci. $15,47-50$.

Katan M. and Parker P. J. (1987) Purification of phosphoinositidespecific phospholipase $C$ from a particulate fraction of bovine brain. Eur. J. Biochem. 168, 413-418.

Kelly E., Batty I., and Nahorski S. R. (1988) Dopamine receptor stimulation does not affect phosphoinositide hydrolysis in slices of rat striatum. $J$. Neurochem. 51, 918-924.

Kendall D. A. and Firth J. L. (1990) Inositol phospholipid hydrolysis in human brain; adenosine inhibition of the response to histamine. Br. J. Pharmacol. 100, 37-40.

Kendall D. A. and Hill S. J. (1988) Adenosine inhibition of histaminestimulated inositol phospholipid hydrolysis in mouse cerebral cortex. J. Neurochem. 50, 497-502.

Kendall D. A. and Nahorski S. R. (1987) Acute and chronic lithium influence agonist and depolarization-stimulated inositol phospholipid hydrolysis in rat cerebral cortex. J. Pharmacol. Exp. Ther. 241, 1023-1027.

Kennington A. S., Hill C. R., Craig J., Bogardus C., Raz I., Ortmeyer H. K., Hansen B. C., Romero G., and Larner J. (1990) Low urinary chiro-inositol excretion in non-insulin-dependent diabetes mellitus. $N$. Engl. J. Med. 323, 373-378.

Kim U. H., Kim J. W., and Rhee S. G. (1989) Phosphorylation of phospholipase C-gamma by cAMP-dependent protein kinase. J. Biol. Chem. 264, 20167-20170.

Klenk E. and Hendricks U. W. (1961) An inositol phosphatide containing carbohydrate, isolated from human brain. Biochim. Biophys. Acta 50, 602-603.

Kloog Y., Ambar I., Sokolovsky M., Kochva E., Wollberg Z., and Bdolah A. (1988) Sarafotoxin, a novel vasoconstrictor peptide: phosphoinositide hydrolysis in rat heart and brain. Science $\mathbf{2 4 2}$, 268-270.

Kloog Y., Ambar I., Kochva E., Wollberg Z., Bdolah A., and Sokolovsky M. (1989) Sarafotoxin receptors mediate phosphoino- sitide hydrolysis in various rat brain regions. FEBS Lett. 242, $387-390$

Kunysz E., Michel A. D., Whiting R. L., and Woods K. (1989) The human astrocytoma cell line $1321 \mathrm{~N} 1$ contains $\mathrm{M}_{2}$-glandular type muscarinic receptors linked to phosphoinositide turnover. Br. J. Pharmacol. 96, 271-278.

Lambert D. G., Ghataorre A. S., and Nahorski S. R. (1989) Muscarinic receptor binding characteristics of a human neuroblastoma SKN-SH and its clones SH-SY-5Y and SH-EP1. Eur. J. Pharmacol. $165,71-77$.

Lee K.-Y., Ryu S. H., Suh P.-G., Choi W. C., and Rhee S. G. (1987) Phospholipase $\mathrm{C}$ associated with particulate fractions of bovine brain. Proc. Natl. Acad. Sci. USA 84, 5540-5544.

Lee S. Y., Sim S. S., Kim J. W., Moon K. H., Kim J. H., and Rhee S. G. (1990) Purification and properties of D-myo-inositol 1,4,5trisphosphate 3-kinase from rat brain. J. Biol. Chem. 265, 94349440.

Lenox R. H., Hendley D., and Ellis J. (1988) Desensitization of muscarinic receptor-coupled phosphoinositide hydrolysis in rat hippocampus: comparisons with the $\alpha_{1}$-adrenergic response. $J$. Neurochem. 50, 558-564.

Lester H. A. (1988) Heterologous expression of excitability proteins: route to more specific drugs? Science 241, 1057-1063.

Li P. P., Sibony D., and Warsh J. J. (1990) Guanosine 5'-O-thiotriphosphate and sodium fluoride activate polyphosphoinositide hydrolysis in rat cortical membranes by distinct mechanisms. J. Neurochem. 54, 1426-1432.

Li X., Song L., and Jope R. S. (1990) Modulation of phosphoinositide metabolism in rat brain slices by excitatory amino acids, arachidonic acid, and GABA. Neurochem. Res. 15, 725-738.

Liang M., Martin M. W., and Harden T. K. (1987) $\left[{ }^{3} \mathrm{H}\right]$ Propylbenzilylcholine mustard-labeling of muscarinic cholinergic receptors that selectively couple to phospholipase $C$ or adenylate cyclase in two cultured cell lines. Mol. Pharmacol. 32, 443-449.

Lin W.-W., Lee C. Y., and Chuang D.-M. (1990) Comparative studies of phosphoinositide hydrolysis induced by endothelin-related peptides in cultured cerebellar astrocytes, $\mathrm{C}_{6}$-glioma and cerebellar granule cells. Biochem. Biophys. Res. Commun. 168, 512519.

Lips D. L. and Majerus P. W. (1989) The discovery of a 3-phosphomonoesterase that hydrolyzes phosphatidylinositol 3-phosphate in NIH 3T3 cells. J. Biol. Chem. 264, 19911-19915.

Lips D. L., Majerus P. W., Gorga F. R., Young A. T., and Benjamin T. L. (1989) Phosphatidylinositol 3-phosphate is present in normal and transformed fibroblasts and is resistant to hydrolysis by bovine brain phospholipase C II. J. Biol. Chem. 264, 87598763.

Lisanti M. P., Rodriguez-Boulan E., and Saltiel A. R. (1990) Emerging functional roles for the glycosylphosphatidylinositol membrane protein anchor. J. Membr. Biol. 117, 1-10.

Litosch I. (1987) Guanine nucleotide and NaF stimulation of phospholipase $\mathrm{C}$ activity in rat cerebral-cortical membranes. Biochem. J. 244, 35-40.

Litosch I. (1989) Guanine nucleotides mediate stimulatory and inhibitory effects on cerebral-cortical membrane phospholipase $\mathrm{C}$ activity. Biochem. J. 261, 245-251.

Lo W. W. Y. and Hughes J. (1988) Differential regulation of cholecystokinin- and muscarinic-receptor-mediated phosphoinositide turnover in Flow 9000 cells. Biochem. J. 251, 625-630.

Low M. G. (1989) Glycosyl-phosphatidylinositol: a versatile anchor for cell surface proteins. FASEB J. 3, 1600-1608.

Low M. G. and Kincade P. W. (1985) Phosphatidylinositol is the membrane-anchoring domain of the Thy-1 glycoprotein. Nature $318,62-64$.

MacCumber M. W., Ross C. A., and Snyder S. H. (1990) Endothelin in brain: receptors, mitogenesis, and biosynthesis in glial cells. Proc. Natl. Acad. Sci. USA 87, 2359-2363.

Maeda N., Niinobe M., Inoue Y., and Mikoshiba K. (1989) Developmental expression and intracellular location of $\mathrm{P}_{400}$ protein characteristic of Purkinje cells in the mouse cerebellum. Dev. Biol. 133, 67-76. 
Maeda N., Niinobe M., and Mikoshiba K. (1990) A cerebellar Purkinje cell marker $\mathbf{P}_{400}$ protein is an inositol 1,4,5-trisphosphate $\left(\mathrm{Ins}_{3}\right.$ ) receptor protein. Purification and characterization of Ins $\mathrm{P}_{3}$ receptor complex. EMBO J. 9, 61-67.

Maeda N., Kawasaki T., Nakade S., Yokota N., Taguchi T., Kasai M., and Mikoshiba K. (1991) Structural and functional characterization of inositol 1,4,5-trisphosphate receptor channel from mouse cerebellum. J. Biol. Chem. 266, 1109-1116.

Mahan L. C., Burch R. M., Monsma F. J. Jr., and Sibley D. R. (1990) Expression of striatal $D_{1}$ dopamine receptors coupled to inositol phosphate production and $\mathrm{Ca}^{2+}$ mobilization in Xenopus oocytes. Proc. Natl. Acad. Sci. USA 87, 2196-2200.

Mailleux P., Takazawa K., Erneux C., and Vanderhaeghen J.-J. (1991) Inositol 1,4,5-trisphosphate 3-kinase mRNA: high levels in the rat hippocampal CA I pyramidal and dentate gyrus granule cells and in cerebellar Purkinje cells. J. Neurochem. 56, 345-347.

Majerus P. W., Ross T. S., Cunningham T. W., Caldwell K. K., Jefferson A. B., and Bansal V. S. (1990) Recent insights in phosphatidylinositol signaling. Cell 63, 459-465.

Malhotra R. K., Bhave S. V., Wakade T. D., Bhave A. S., and Wakade A. R. (1990) Effects of neurotransmitters and peptides on phospholipid hydrolysis in sympathetic and sensory neurons. FASEB J. 4, 2492-2498.

Mallet J., Huchet M., Pougeois R., and Changeux J.-P. (1976) Anatomical, physiological and biochemical studies on the cerebellum from mutant mice. III. Protein differences associated with the weaver, staggerer and nervous mutations. Brain Res. 103, 291-312.

Manzoni O., Fagni L., Pin J.-P., Rassendren F., Poulat F., Sladeczek F., and Bockaert J. (1990) (trans)-1-Amino-cyclopentyl-1,3-dicarboxylate stimulates quisqualate phosphoinositide-coupled receptors but not ionotropic glutamate receptors in striatal neurons and Xenopus oocytes. Mol. Pharmacol. 38, 1-6.

Margolis R. K., Goossen B., and Margolis R. U. (1988) Phosphatidylinositol-anchored glycoproteins of $\mathrm{PC} 12$ pheochromocytoma cells and brain. Biochemistry 27, 3454-3458.

Masu M., Tanabe Y., Tsuchida K., Shigemoto R., and Nakanishi S. (1991) Sequence and expression of a metabotropic glutamate receptor. Nature 349, 760-765.

Mau S. E., Larsen P. J., Mikkelsen J. A., and Særmark T. (1990) Substance $\mathbf{P}$ and related tachykinins induce receptor-mediated hydrolysis of polyphosphoinositides in the rat anterior pituitary. Mol. Cell. Endocrinol. 69, 69-78.

McAtee P. and Dawson G. (1990) Phospholipase C activity in NCB20 cells is inhibited by protein kinase A-mediated phosphorylation of low molecular mass GTP-binding proteins. J. Biol. Chem. 265, 6788-6793.

Meek J. L., Rice T. J., and Anton E. (1988) Rapid purification of inositol monophosphate phosphatase from beef brain. Biochem. Biophys. Res. Commun. 156, 143-148.

Meyer T., Holowka D., and Stryer L. (1988) Highly cooperative opening of calcium channels by inositol 1,4,5-trisphosphate. Science 240, 653-655.

Michel M. C., Hanft G., and Gross G. (1990) $\alpha_{1 \mathrm{~B}^{-}}$but not $\alpha_{1 \mathrm{~A}^{-a d}-}$ renoceptors mediate inositol phosphate generation. NaunynSchmiedebergs Arch. Pharmacol. 341, 385-387.

Mignery G. A., Südhof T. C., Takei K., and De Camilli P. (1989) Putative receptor for inositol 1,4,5-trisphosphate similar to ryanodine receptor. Nature 342, 192-195.

Mignery G. A., Newton C. L., Archer B. T. III, and Südhof T. C. (1990) Structure and expression of the rat inositol 1,4,5-trisphosphate receptor. J. Biol. Chem. 265, 12679-12685.

Minneman K. P. (1988) $\alpha_{1}$-Adrenergic receptor subtypes, inositol phosphates, and sources of cell $\mathrm{Ca}^{2+}$. Pharmacol. Rev. 40, 87119.

Misawa H., Ueda H., and Satoh M. (1990) $\kappa$-Opioid agonist inhibits phospholipase $C_{1}$ possibly via an inhibition of G-protein activity. Neurosci. Lett. 112, 324-327.

Moratalla R., Vallejo M., and Lightman S. L. (1988) Vasopressin stimulates inositol phospholipid metabolism in rat medulla oblongata in vivo. Brain Res. 450, 398-402.
Morgan S. J., Smith A. D., and Parker P. J. (1990) Purification and characterization of bovine brain type I phosphatidylinositol kinase. Eur. J. Biochem. 191, 761-767.

Moritz A., De Graan P. N. E., Ekhart P. F., Gispen W. H., and Wirtz K. W. A. (1990) Purification of a phosphatidylinositol 4-phosphate kinase from bovine brain membranes. J. Neurochem. 54, 351-354.

Moroi-Fetters S. E., Neff N. H., and Hadjiconstantinou M. (1988) Muscarinic receptor-mediated phosphoinositide hydrolysis in the rat retina. J. Pharmacol. Exp. Ther. 246, 553-557.

Morrisett R. A., Chow C. C., Sakaguchi T., Shin C., and McNamara J. O. (1990) Inhibition of muscarinic-coupled phosphoinositide hydrolysis by $N$-methyl-D-aspartate is dependent on depolarization via channel activation. J. Neurochem. 54, 1517-1525.

Moyer J. D., Reizes O., Ahir S., Jiang C., Malinowski N., and Baker D. C. (1988) Substrate properties of analogs of myo-inositol. Mol. Pharmacol. 33, 683-689.

Murphy S. and Welk G. (1990) Hydrolysis of polyphosphoinositides in astrocytes by platelet-activating factor. Eur. J. Pharmacol. $188,399-401$.

Nahorski S. R. and Potter B. V. L. (1989) Molecular recognition of inositol polyphosphates by intracellular receptors and metabolic enzymes. Trends Pharmacol. Sci. 10, 139-144.

Nakahata N. and Harden T. K. (1987) Regulation of inositol trisphosphate accumulation by muscarinic cholinergic and $\mathrm{H}_{1}$-histamine receptors on human astrocytoma cells. Biochem. J. 241, 337-344.

Nakahata N., Matsuoka I., Ono T., and Nakanishi H. (1989) Thromboxane $A_{2}$ activates phospholipase $C$ in astrocytoma cells via pertussis toxin-insensitive G-protein. Eur. J. Pharmacol. 162, 407-417.

Nakahata N., Abe M. T., Matsuoka I., and Nakanishi H. (1990) Mastoparan inhibits phosphoinositide hydrolysis via pertussis toxin-insensitive G-protein in human astrocytoma cells. FEBS Lett. 260, 91-94.

Negishi M., Ito S., and Hayaishi O. (1989) Prostaglandin E receptors in bovine adrenal medulla are coupled to adenylate cyclase via $\mathrm{G}_{\mathrm{i}}$ and to phosphoinositide metabolism in a pertussis toxin-insensitive manner. J. Biol. Chem. 264, 3916-3923.

Nicoletti F. and Canonico P. L. (1989) Glycine potentiates the stimulation of inositol phospholipid hydrolysis by excitatory amino acids in primary cultures of cerebellar neurons. $J$. Neurochem. 53, 724-727.

Nicoletti F., Wroblewski J. T., Alho H., Eva C., Fadda E., and Costa E. (1987) Lesions of putative glutamatergic pathways potentiate the increase of inositol phospholipid hydrolysis elicited by excitatory amino acids. Brain Res. 436, 103-112.

Nicoletti F., Wroblewski J. T., Fadda E., and Costa E. (1988) Pertussis toxin inhibits signal transduction at a specific metabolotropic glutamate receptor in primary cultures of cerebellar granule cells. Neuropharmacology 27, 551-556.

Nicoletti F., Bruno V., Cavallaro S., Copani A., Sortino M. A., and Canonico P. L. (1990) Specific binding sites for inositolhexakisphosphate in brain and anterior pituitary. Mol. Pharmacol. 37, 689-693.

Nishizuka Y. (1988) The molecular heterogeneity of protein kinase $\mathrm{C}$ and its implications for cellular regulation. Nature 334, 661665.

Noble E. P., Sincini E., Bergmann J., and ten Bruggencate G. (1989) Excitatory amino acids inhibit stimulated phosphoinositide hydrolysis in the rat prefrontal cortex. Life Sci. 44, 19-26.

Nunn D. L., Potter B. V. L., and Taylor C. W. (1990) Molecular target sizes of inositol 1,4,5-trisphosphate receptors in liver and cerebellum. Biochem. J. 265, 393-398.

Oakes S. G., Iaizzo P. A., Richelson E., and Powis G. (1988) Histamine-induced intracellular free $\mathrm{Ca}^{++}$, inositol phosphates and electrical changes in murine N1E-115 neuroblastoma cells. $J$. Pharmacol. Exp. Ther. 247, 114-121.

Orellana S., Solski P. A., and Brown J. H. (1987) Guanosine 5'-O(thiotriphosphate)-dependent inositol triphosphate formation in 
membranes is inhibited by phorbol ester and protein kinase $C$. J. Biol. Chem. 262, 1638-1643.

Osborne N. N. (1990) Stimulatory and inhibitory actions of excitatory amino acids on inositol phospholipid metabolism in rabbit retina. Evidence for a specific quisqualate receptor subtype associated with neurones. Exp. Eye Res. 50, 397-405.

Osborne N. N. and Ghazi H. (1989) The effect of substance P and other tachykinins on inositol phospholipid hydrolysis in rabbit retina, superior colliculus and retinal cultures. Vision Res. 29, 757-764.

Palmer E., Monaghan D. T., and Cotman C. W. (1989) trans-ACPD, a selective agonist of the phosphoinositide-coupled excitatory amino acid receptor. Eur. J. Pharmacol. 166, 585-587.

Patel J., Moore W. C., Thompson C., Keith R. A., and Salama A. I. (1990) Characterization of the quisqualate receptor linked to phosphoinositide hydrolysis in neurocortical cultures. J. Neurochem. 54, 1461-1466.

Pearce B., Morrow C., and Murphy S. (1988) Characteristics of phorbol ester- and agonist-induced down-regulation of astrocyte receptors coupled to inositol phospholipid metabolism. J. Neurochem. 50, 936-944.

Pearce B., Murphy S., Jeremy J., Morrow C., and Dandona P. (1989) ATP-evoked $\mathrm{Ca}^{2+}$ mobilisation and prostanoid release from astrocytes: $P_{2}$-purinergic receptors linked to phosphoinositide hydrolysis. J. Neurochem. 52, 971-977.

Pearce B., Morrow C., and Murphy S. (1990) Further characterisation of excitatory amino acid receptors coupled to phosphoinositide metabolism in astrocytes. Neurosci. Lett. 113, 298-303.

Periyasamy S. and Hoss W. (1990) Kappa opioid receptors stimulate phosphoinositide turnover in rat brain. Life Sci. 47, 219-225.

Perney T. M. and Miller R. J. (1989) Two different G-proteins mediate neuropeptide $Y$ and bradykinin-stimulated phospholipid breakdown in cultured rat sensory neurons. J. Biol. Chem. 264, 73177327.

Pfeilschifter J. (1990) Comparison of extracellular ATP and UTP signalling in rat renal mesangial cells. Biochem. J. 272, 469472.

Pierce P. A. and Peroutka S. J. (1988) Antagonism of 5hydroxytryptamine ${ }_{2}$ receptor-mediated phosphatidylinositol turnover by $d$-lysergic acid diethylamide. J. Pharmacol. Exp. Ther. 247, 918-925.

Poyner D. R., Hawkins P. T., Benton H. P., and Hanley M. R. (1990) Changes in inositol lipids and phosphates after stimulation of the MAS-transfected NG 115-401L-C3 cell line by mitogenic and non-mitogenic stimuli. Biochem. J. 271, 605-611.

Prasad V. N. H. and Moody T. W. (1989) Bombesin-like peptides stimulate phosphatidylinositol turnover in rat brain slices. Peptides 9, 1345-1349.

Ragan C. I., Watling K. J., Gee N. S., Aspley S., Jackson R. G., Reid G. G., Baker R., Billington D. C., Barnaby R. J., and Leeson P. D. (1988) The dephosphorylation of inositol 1,4-bisphosphate to inositol in liver and brain involves two distinct $\mathrm{Li}^{+}$-sensitive enzymes and proceeds via inositol 4-phosphate. Biochem. J. 249, 143-148.

Raiteri M., Marchi M., and Paudice P. (1987) Vasoactive intestinal polypeptide (VIP) potentiates the muscarinic stimulation of phosphoinositide turnover in rat cerebral cortex. Eur. I. Pharmacol. 133, 127-128.

Rebecchi M. J. and Rosen O. M. (1987) Purification of a phosphoinositide-specific phospholipase $\mathrm{C}$ from bovine brain. $J$. Biol. Chem. 262, 12526-12532.

Rhee S. G., Suh P.-G., Ryu S.-H., and Lee S. Y. (1989) Studies of inositol phospholipid-specific phospholipase C. Science 244, 546550.

Robertson P. L., Bruno G. R., and Datta S. C. (1990) Glutamatestimulated, guanine nucleotide-mediated phosphoinositide turnover in astrocytes is inhibited by cyclic AMP. J. Neturochem. $55,1727-1733$.

Ross C. A., Meldolesi J., Milner T. A., Satoh T., Supattapone S., and Snyder S. H. (1989) Inositol 1,4,5-trisphosphate receptor localized to endoplasmic reticulum in cerebellar Purkinje neurons. Nature 339, 468-470.

Rubinstein J. E. and Hitzemann R. J. (1990) Further evidence against the coupling of dopamine receptors to phosphoinositide hydrolysis in rat striatum. Biochem. Pharmacol. 39, 1965-1970.

Ryu S. H., Cho K. S., Lee K. Y., Suh P.-G., and Rhee S. G. (1986) Two forms of phosphatidylinositol-specific phospholipase $C$ from bovine brain. Biochem. Biophys. Res. Commun. 141, 137-144.

Ryu S. H., Cho K. S., Lee K.-Y., Suh P.-G., and Rhee S. G. (1987a) Purification and characterization of two immunologically distinct phosphoinositide-specific phospholipase $\mathrm{C}$ from bovine brain. J. Biol. Chem. 262, 12511-12518.

Ryu S. H., Suh P.-G., Cho K. S., Lee K.-Y., and Rhee S. G. (1987b) Bovine brain cytosol contains three immunologically distinct forms of inositolphospholipid-specific phospholipase C. Proc. Natl. Acad. Sci. USA 84, 6649-6653.

Saltiel A. R., Fox J. A., Sherline P., Sahyoun N., and Cuatrecasas P. (1987) Purification of phosphatidylinositol kinase from bovine brain myelin. Biochem. J. 241, 759-763.

Sanders-Bush E., Burris K. D., and Knoth K. (1988) Lysergic acid diethylamide and 2,5-dimethoxy-4-methylamphetamine are partial agonists at serotonin receptors linked to phosphoinositide hydrolysis. J. Pharmacol. Exp. Ther. 246, 924-928.

Sasakawa N., Nakaki T., Yamamoto S., and Kato R. (1989) Stimulation by ATP of inositol trisphosphate accumulation and calcium mobilization in cultured adrenal chromaffin cells. $J$. Neurochem. 52, 441-447.

Sasakawa N., Nakaki T., and Kato R. (1990) Stimulus-responsive and rapid formation of inositol pentakisphosphate in cultured adrenal chromaffin cells. J. Biol. Chem. 265, 17700-17705.

Satoh T., Ross C. A., Villa A., Supattapone S., Pozzan T., Snyder S. H., and Meldolesi J. (1990) The inositol 1,4,5-trisphosphate receptor in cerebellar Purkinje cells: quantitative immunogold labeling reveals concentration in an ER subcompartment. J. Cell Biol. 111, 615-624.

Schoepp D. D., Johnson B. G., Smith E. C. R., and McQuaid L. A. (1990a) Stereoselectivity and mode of inhibition of phosphoinositide-coupled excitatory amino acid receptors by 2-amino3-phosphonopropionic acid. Mol. Pharmacol. 38, 222-228.

Schoepp D., Bockaert J., and Sladeczek F. (1990b) Pharmacological and functional characteristics of metabotropic excitatory amino acid receptors. Trends Pharmacol. Sci. 11, 508-515.

Seren M. S., Aldinio C., Zanoni R., Leon A., and Nicoletti F. (1989) Stimulation of inositol phospholipid hydrolysis by excitatory amino acids is enhanced in brain slices from vulnerable regions after transient global ischemia. J. Neurochem. 53, 1700-1705.

Serra M., Mei L., Roeske W. R., Lui G. K., Watson M., and Yamamura H. 1. (1988) The intact human neuroblastoma cell (SHSY5Y) exhibits high-affinity $\left[{ }^{3} \mathrm{H}\right]$ pirenzepine binding associated with hydrolysis of phosphatidylinositols. J. Neurochem. $\mathbf{5 0}$, 1513-1521.

Serunian L. A., Haber M. T., Fukui T., Kim J. W., Rhee S. G., Lowenstein J. M., and Cantley L. C. (1989) Polyphosphoinositides produced by phosphatidylinositol 3-kinase are poor substrates for phospholipases $\mathrm{C}$ from rat liver and bovine brain. $J$. Biol. Chem. 264, 17809-17815.

Sharif N. A., Hunter J. C., Hill R. G., and Hughes J. (1988) Bradykinin-induced accumulation of $\left[{ }^{3} \mathrm{H}\right]$ inositol-1-phosphate in human embryonic pituitary tumour cells by activation of a $\mathbf{B}_{2}$ receptor. Neurosci. Lett. 86, 279-283.

Sharif N. A., To Z., and Whiting R. L. (1989) First pharmacological characterization of TRH receptors linked to phosphoinositide hydrolysis in GH3 pituitary cells using agonist specificity of eight TRH analogs. Biochem. Biophys. Res. Commun. 161, 13061311.

Shears S. B. (1989) Metabolism of the inositol phosphates produced upon receptor activation. Biochem. J. 260, 313-324.

Shewey L. M. and Dorsa D. M. (1988) $\mathrm{V}_{1}$-type vasopressin receptors in rat brain septum: binding characteristics and effects on inositol phospholipid metabolism. J. Neurosci. 8, 1671-1677. 
Sim S. S., Kim J. W., and Rhee S. G. (1990) Regulation of D-myoinositol 1,4,5-trisphosphate 3-kinase by cAMP-dependent protein kinase and protein kinase C. J. Biol. Chem. 265, 10367-10372

Smith C. D. and Chang K.-J. (1989) Regulation of brain phosphatidylinositol-4-phosphate kinase by GTP analogues. J. Biol. Chem. 264, 3206-3210.

Smith R. J., Sam L. M., Justen J. M., Bundy G. L., Bala G. A., and Bleasdale J. E. (1990) Receptor-coupled signal transduction in human polymorphonuclear neutrophils: effects of a novel inhibitor of phospholipase $\mathrm{C}$-dependent processes on cell responsiveness. J. Pharmacol. Exp. Ther. 253, 688-697.

Smrcka A. V., Hepler J. R., Brown K. O., and Sternweis P. C. (1991) Regulation of polyphosphoinositide-specific phospholipase C activity by purified $G_{\mathrm{q}}$. Science $251,804-807$.

Snyder S. H. and Supattapone S. (1989) Isolation and functional characterization of an inositol trisphosphate receptor from brain. Cell Calcium 10, 337-342.

Sortino M. A., Evans W. S., Speciale C., Thorner M. O., Scapagnini U., MacLeod R. M., and Canonico P. L. (1988) Gonadotropinreleasing hormone-stimulated phosphoinositide hydrolysis in the anterior pituitary. Neuroendocrinology 48, 544-550.

Sortino M. A., Nicoletti F., and Canonico P. L. (1990) Inositol hexakisphosphate stimulates ${ }^{45} \mathrm{Ca}^{2+}$ uptake in anterior pituitary cells in culture. Eur. J. Pharmacol. 189, 115-118.

Spät A., Bradford P. G., McKinney J. S., Rubin R. P., and Putney J. W. Jr. (1986) A saturable receptor for ${ }^{32}$ P-inositol-1,4,5-trisphosphate in hepatocytes and neutrophils. Nature 319, 514516.

Stanley A. F., Hawkins P. T., and Hanley M. R. (1990) Inositol hexakisphosphate biosynthesis in mammalian brain: identification of a novel inositol pentakisphosphate kinase. Biochem. Soc. Trans. 18, 460-461.

Stephens L. R., Hawkins P. T., Barker C. J., and Downes C. P. (1988) Synthesis of myo-inositol 1,3,4,5,6-pentakisphosphate from inositol phosphates generated by receptor activation. Biochem. J. 253, 721-733.

Stephens L., Hawkins P. T., and Downes C. P. (1989) Metabolic and structural evidence for the existence of a third species of polyphosphoinositide in cells: D-phosphatidyl-myo-inositol 3-phosphate. Biochem. J. 259, 267-276.

Strosznajder J. and Strosznajder R. P. (1989) Stimulation of phosphoinositide degradation and phosphatidylinositol-4-phosphate phosphorylation by GTP exclusively in plasma membrane of rat brain. Neurochem. Res. 14, 717-723.

Supattapone S., Worley P. F., Baraban J. M., and Snyder S. H. (1988) Solubilization, purification, and characterization of an inositol trisphosphate receptor. J. Biol. Chem. 263, 1530-1534.

Sylvia V., Curtin G., Norman J., Stec J., and Busbee D. (1988) Activation of a low specific activity form of DNA polymerase $\alpha$ by inositol-1,4-bisphosphate. Cell 54, 651-658.

Takashima A. and Kenimer J. G. (1989) Muscarinic-stimulated norepinephrine release and phosphoinositide hydrolysis in $\mathrm{PC12}$ cells are independent events. J. Biol. Chem. 264, 10654-10659.

Takazawa K., Passareiro H., Dumont J. E., and Erneux C. (1988) $\mathrm{Ca}^{2+} /$ calmodulin-sensitive inositol 1,4,5-trisphosphate 3-kinase in rat and bovine brain tissues. Biochem. Biophys. Res. Commun. $153,632-641$.

Takazawa K., Lemos M., Delvaux A., Lejeune C., Dumont J. E., and Erneux C. (1990a) Rat brain inositol 1,4,5-trisphosphate 3kinase. Biochem. $J$. 268, 213-217.

Takazawa K., Vandekerckhove J., Dumont J. E., and Erneux C. $(1990 \mathrm{~b})$ Cloning and expression in Escherichia coli of a rat brain cDNA encoding a $\mathrm{Ca}^{2+} /$ calmodulin-sensitive inositol 1,4,5-trisphosphate 3-kinase. Biochem. J. 272, 107-112.

Taylor S. J., Chae H. Z., Rhee S. G., and Exton J. H. (1991) Activation of the $\beta 1$ isozyme of phospholipase $C$ by $\alpha$ subunits of the $G_{q}$ class of $\mathrm{G}$ protein. Nature 350, 516-518.

Thompson A. K. and Fisher S. K. (1990) Relationship between agonist-induced muscarinic receptor loss and desensitization of stimulated phosphoinositide turnover in two neuroblastomas: methodological considerations. J. Pharmacol. Exp. Ther. 252, 744-752.

Thompson A. K. and Fisher S. K. (1991) Preferential coupling of cell surface muscarinic receptors to phosphoinositide hydrolysis in human neuroblastoma cells. J. Biol. Chem. 266, 5004-5010.

Thompson A. K., Mostafapour S. P., Denlinger L. C., Bleasdale J. E., and Fisher S. K. (1991) The aminosteroid U-73122 inhibits muscarinic receptor sequestration and phosphoinositide hydrolysis in SK-N-SH neuroblastoma cells: a role for $\mathrm{G}_{\mathrm{p}}$ in receptor compartmentation. J. Biol. Chem. (in press).

Torrens Y., Daguet De Montety M. C., El Etr M., Beaujouan J. C., and Glowinski J. (1989) Tachykinin receptors of the NK1 type (substance P) coupled positively to phospholipase C on cortical astrocytes from the newborn mouse in primary culture. $J$. Neurochem. 52, 1913-1918.

Undie A. S. and Friedman E. (1990) Stimulation of a dopamine $D_{1}$ receptor enhances inositol phosphate formation in rat brain. $J$. Pharmacol. Exp. Ther. 253, 987-992.

Vadnal R. E. and Parthasarathy R. (1989) The identification of a novel inositol lipid, phosphatidylinositol trisphosphate $\left(\mathrm{PIP}_{3}\right)$, in rat cerebrum using in vivo techniques. Biochem. Biophys. Res. Commun. 163, 995-1001.

Vallejo M., Jackson T., Lightman S., and Hanley M. R. (1987) Occurrence and extracellular actions of inositol pentakis- and hexakisphosphate in mammalian brain. Nature 330, 656-658.

Van Calker D., Takahata K., and Heumann R. (1989) Nerve growth factor potentiates the hormone-stimulated intracellular accumulation of inositol phosphates and $\mathrm{Ca}^{2+}$ in rat $\mathrm{PCl} 2$ pheochromocytoma cells: comparison with the effect of epidermal growth factor. J. Neurochem. 52, 38-45.

Van der Merwe P. A., Wakefield I. K., Fine J., Millar R. P., and Davidson J. S. (1989) Extracellular adenosine triphosphate activates phospholipase $C$ and mobilizes intracellular calcium in primary cultures of sheep anterior pituitary cells. FEBS Lett. 243, 333-336.

Van Dongen C. J., Zwiers H., and Gispen W. H. (1984) Purification and partial characterization of the phosphatidylinositol 4-phosphate kinase from rat brain. Biochem. J. 223, 197-203.

Van Hooff C. O. M., De Graan P. N. E., Oestreicher A. B., and Gispen W. H. (1988) B-50 phosphorylation and polyphosphoinositide metabolism in nerve growth cone membranes. $J$. Neurosci. 8, 1789-1795.

Varney M. A., Rivera J., Lopez-Bernal A., and Watson S. P. (1990) Are there subtypes of the inositol 1,4,5-trisphosphate receptor? Biochem. J. 269, 211-216.

Volonté C. and Racker E. (1988) Lithium stimulation of membranebound phospholipase $\mathrm{C}$ from $\mathrm{PC} 12$ cells exposed to nerve growth factor. $J$. Neurochem. 51, 1163-1168.

Volonté C., Parries G. S., and Racker E. (1988) Stimulation of inositol incorporation in lipids of PC 12 cells by nerve growth factor and bradykinin. J. Neurochem. 51, 1156-1162.

Wakui M., Potter B. V. L., and Petersen O. H. (1989) Pulsatile intracellular calcium release does not depend on fluctuations in inositol trisphosphate concentration. Nature 339, 317-320,

Wallace M. A. and Claró E. (1990) A novel role for dopamine: inhibition of muscarinic cholinergic-stimulated phosphoinositide hydrolysis in rat brain cortical membranes. Neurosci. Lett. 110, 155-161.

Whitman M., Kaplan D., Roberts T., and Cantley L. (1987) Evidence for two distinct phosphatidylinositol kinases in fibroblasts. Biochem. J. 247, 165-174.

Willcocks A. L., Cooke A. M., Potter B. V. L., and Nahorski S. R. (1987) Stereospecific recognition sites for $\left[{ }^{3} \mathrm{H}\right]$ inositol $(1,4,5)$ trisphosphate in particulate preparations of rat cerebellum Biochem. Biophys. Res. Commun. 146, 1071-1078.

Willcocks A. L., Potter B. V. L., Cooke A. M., and Nahorski S. R. (1988) myo-Inositol (1,4,5)-triphosphorothionate binds to specific $\left[{ }^{3} \mathrm{H}\right]$ inositol- $(1,4,5)$ trisphosphate sites in rat cerebellum and is resistant to 5-phosphatase. Eur. J. Pharmacol. 155, 181-183.

Wilson K. M. and Minneman K. P. (1990) Pertussis toxin inhibits 
norepinephrine-stimulated inositol phosphate formation in primary brain cell cultures. Mol. Pharmacol. 38, 274-281.

Wilson K. M., Gilchrist S., and Minneman K. P. (1990) Comparison of $\alpha_{1}$-adrenergic receptor-stimulated inositol phosphate formation in primary neuronal and glial cultures. $J$. Neurochem. 55, 691-697.

Wojcikiewicz R. J. H. and Nahorski S. R. (1989) Phosphoinositide hydrolysis in permeabilized SH-SY5Y human neuroblastoma cells is inhibited by mastoparan. FEBS Lett. 247, 341-344.

Wong Y.-H. H., Kalmbach S. J., Hartman B. K., and Sherman W. R. (1987) Immunohistochemical staining and enzyme activity measurements show myo-inositol-1-phosphate synthase to be localized in the vasculature of brain. $J$. Neurochem. 48,1434 1442.

Wood C. A. and Schofield J. G. (1989) The effects of thyrotropinreleasing hormone and potassium depolarization on phosphoinositide metabolism and cytoplasmic calcium in bovine pituitary cells. Biochim. Biophys. Acta 1013, 97-106.

Worley P. F., Baraban J. M., Colvin J. S., and Snyder S. H. (1987a) Inositol trisphosphate receptor localization in brain: variable stoichiometry with protein kinase C. Nature 325, 159-161.

Worley P. F., Baraban J. M., Supattapone S., Wilson V. S., and Snyder S. H. (1987b) Characterization of inositol trisphosphate receptor binding in brain. Regulation by $\mathrm{pH}$ and calcium. $J$. Biol. Chem. 262, 12132-12136.

Worley P. F., Baraban J. M., and Snyder S. H. (1989) Inositol 1,4,5trisphosphate receptor binding: autoradiographic localization in rat brain. J. Neurosci. 9, 339-346.

$\mathrm{Xu}$ J. and Chuang D.-M. (1987a) Muscarinic acetylcholine receptormediated phosphoinositide turnover in cultured cerebellar granule cells: desensitization by receptor agonists. J. Pharmacol. Exp. Ther. 242, 238-242.

Xu J. and Chuang D.-M. (1987b) Serotonergic, adrenergic and histaminergic receptors coupled to phospholipase $C$ in cultured cerebellar granule cells of rats. Biochem. Pharmacol. 36, 2353 2358.

Yamakawa A. and Takenawa T. (1988) Purification and characterization of membrane-bound phosphatidylinositol kinase from rat brain. J. Biol. Chem. 263, 17555-17560.

Yu O. and Chuang D.-M. (1988) GABA pretreatment enhances glutamate mediated phosphoinositide hydrolysis in neurons. Eur. J. Pharmacol. 158, 179-180.

Zhang W., Sakai N., Yamada H., Fu T., and Nozawa Y. (1990) Endothelin-1 induces intracellular calcium rise and inositol 1,4,5trisphosphate formation in cultured rat and human glioma cells. Neurosci. Lett. 112, 199-204. 